\title{
Recovery of DNA Profiles from Fingerprints on Paper after the Application of Ninhydrin or DFO Given Certain Time Periods
}

\author{
Marco Colin Lovejoy \\ West Virginia University
}

Follow this and additional works at: https://researchrepository.wvu.edu/etd

\author{
Recommended Citation \\ Lovejoy, Marco Colin, "Recovery of DNA Profiles from Fingerprints on Paper after the Application of \\ Ninhydrin or DFO Given Certain Time Periods" (2012). Graduate Theses, Dissertations, and Problem \\ Reports. 4890. \\ https://researchrepository.wvu.edu/etd/4890
}

This Thesis is protected by copyright and/or related rights. It has been brought to you by the The Research Repository @ WVU with permission from the rights-holder(s). You are free to use this Thesis in any way that is permitted by the copyright and related rights legislation that applies to your use. For other uses you must obtain permission from the rights-holder(s) directly, unless additional rights are indicated by a Creative Commons license in the record and/ or on the work itself. This Thesis has been accepted for inclusion in WVU Graduate Theses, Dissertations, and Problem Reports collection by an authorized administrator of The Research Repository @ WVU. For more information, please contact researchrepository@mail.wvu.edu. 


\title{
Recovery of DNA Profiles from Fingerprints on Paper after the Application of Ninhydrin or DFO \\ Given Certain Time Periods
}

\author{
Marco Colin Lovejoy \\ Thesis submitted to the \\ Eberly College of Arts and Sciences \\ at West Virginia University \\ in partial fulfillment of the requirements \\ for the degree of
}

\begin{abstract}
Master of Science
in

Forensic and Investigative Science

Keith B. Morris, Ph.D., Chair

Tina M. Moroose, M.S.

Clifton P. Bishop, Ph.D.
\end{abstract}

Department of Forensic and Investigative Science

\author{
Morgantown, West Virginia \\ 2012
}

Keywords: DNA Analysis, Fingerprints, Paper, Ninhydrin, DFO, Time Periods

Copyright 2012 Marco Colin Lovejoy 


\title{
ABSTRACT \\ Recovery of DNA Profiles from Fingerprints on Paper after the Application of Ninhydrin or DFO Given Certain Time Periods
}

\author{
Marco Colin Lovejoy
}

This study examined the recovery of DNA profiles from fingerprints on paper. This examination occurred in three phases: initial determination of DNA profiles on paper, recovery of DNA profiles given certain time periods, and recovery of DNA profiles after the application of the chemical enhancement techniques of ninhydrin or DFO given certain time periods. Phase II and Phase III paper sheets were exposed to the environment to simulate a house setting. All samples from the phases were extracted with phenol-chloroform. Samples from Phase I and Phase II were amplified with AMPFlSTR® Identifiler ${ }^{\circledR}$ amplification kit while samples from Phase III were amplified with Promega Power Plex ® 16 amplification kit. Phase I samples contained, on average, the most amount of DNA with $21.05 \mathrm{pg} / \mu \mathrm{L}$. Phase III samples contained, on average, the lowest amount of DNA with $.56 \mathrm{pg} / \mu \mathrm{L}$. It was found that no profiles were recovered from the samples after analysis. It is not recommended to perform DNA analysis after the application of ninhydrin and DFO on paper unless all other options have been exhausted. 


\section{Table of Contents}

Title Page___ i

Abstract___ ii

Table of Contents___ iii

List of Figures___ iv

List of Equations___ iv

List of Tables__ _ $\mathrm{V}$

I. Literature Review

II. Materials/Methods

Phase I - Initial determination of DNA profiles__ 25

Phase II - Recovery of DNA Profiles given Certain Time Periods____ 31

Phase III - Recovery of DNA Profiles given the Application of Ninhydrin or DFO given Certain Time Periods

III. Results

IV. Discussion 42

V. Future Research _ 47

VI. Acknowledgements

VII. References 48 


\section{List of Figures}

Figure 1: Overview of TaqMan®- Probe-Based Assay Chemistry (Courtesy of Life Technologies and Applied Biosystems ${ }^{\mathrm{TM}}$ ) 8

Figure 2: Average DNA Concentration $(\mathrm{pg} / \mu \mathrm{L})$ from Phase I Quantitation 35

Figure 3: Average DNA Concentration and Standard Deviation $(\mathrm{pg} / \mu \mathrm{L})$ per Hour Period from Phase II Quantitation 38

Figure 4: Comparison of the Average Amount of DNA (pg/ $\mu \mathrm{L})$ and Standard Deviation $(\mathrm{pg} / \mu \mathrm{L})$ from the Application of Ninhydrin or DFO from Phase III

\section{List of Equations}

Equation 1: Determination of the amount of master mix needed for quantitation 28

Equation 2: Calculation of Amplification Master Mix for AMPFISTR ${ }^{\circledR}$ Identifiler ${ }^{\circledR}$ 29

Equation 3: Calculation of the analysis solution (Hi-DiTM Formamide/GeneScan ${ }^{\text {TM }}-500$ LIZ ${ }^{\text {TM }}$ Size Standard) 30

Equation 4: Calculation of Amplification Master Mix for Power Plex® 16 32 


\section{List of Tables}

Table 1: Creation of Standard Concentrations for Quantitation 28

Table 2: Parameters for the Identifiler® LCN Profile Run Setup on the ThermoCycler PCR System 9700 30

Table 3: Parameters for the Power Plex ${ }^{\circledR} 16$ Run Setup on the ThermoCycler PCR System 9700 32

Table 4: Quantitation Results from Phase I in $(\mathrm{ng} / \mu \mathrm{L})$ and in $(\mathrm{pg} / \mu \mathrm{L})$ 34

Table 5: Average amount of DNA $(\mathrm{pg} / \mu \mathrm{L})$ and Standard Deviation $(\mathrm{pg} / \mu \mathrm{L})$ per Set from the Same Time Process and the Sequence Process from Phase I Quantitation 35

Table 6: Quantitation Results from Phase II in $(\mathrm{ng} / \mu \mathrm{L})$ and in $(\mathrm{pg} / \mu \mathrm{L})$ 37

Table 7: Average amount of DNA $(\mathrm{pg} / \mu \mathrm{L})$ and Standard Deviation $(\mathrm{pg} / \mu \mathrm{L})$ per Hour Period from Phase II Quantitation 38

Table 8: Quantitation Results from Phase III in $(\mathrm{ng} / \mu \mathrm{L})$ and in $(\mathrm{pg} / \mu \mathrm{L})$ 40

Table 9: Average Amount of DNA (pg/ $\mu \mathrm{L})$ and Standard Deviation $(\mathrm{pg} / \mu \mathrm{L})$ from the Application of Ninhydrin or DFO from Phase III 


\section{Literature Review}

The discipline of forensic biology has been around since the early $20^{\text {th }}$ century. Examiners would determine the characteristics of bodily fluids and determine a person's blood type if blood was present. Blood types could be categorized into classes. However, the characteristics of the bodily fluids and blood type classes were not enough for individualization. Fortunately, each bodily fluid contained a small molecule called deoxyribonucleic acid or DNA. The DNA molecule could be typed and used for individualization. The first explanation of DNA typing occurred with Alec Jeffreys in 1984 when he first discovered that certain areas of DNA sequences repeat over and over again [1]. He also found that these sequences could vary in the number of repeated sequences. It is known that a cell is the basic unit of life. A eukaryotic cell is composed of a nucleus that contains 92 strands of deoxyribose nucleic acid or DNA. These DNA strands contain the blueprint on how to build and maintain the cell with various amounts of enzymes and have the capability to store genetic makeup from the past and transfer it to the future [2].

The entire genetic makeup of DNA is called a genome. The basic structure of DNA is made up of three parts: a nucleotide, a sugar, and a phosphate group. There are four nucleotides in DNA: adenine (A), guanine $(\mathrm{G})$, thymine $(\mathrm{T})$, and cytosine $(\mathrm{C})$. These four bases are paired up with its complementary base depending on hydrogen bonding and Van Der Waal forces [3]. For example, adenine bonds to thymine with two hydrogen bonds while cytosine bonds to guanine with three hydrogen bonds. These pairings of bases allow the DNA structure to curve into its easily recognizable double helix formation as founded by Dr. Watson and Dr. Crick [3]. Humans have about 3 billion nucleotide positions in the DNA structure [2]. These bases can line up in any combination at any position to give over a vast amount of combinations, possibly in the 
trillions. It is no wonder that with the exception of identical twins, there are no two genetic profiles that are the same.

DNA strands are packaged in the form of chromosomes. In humans, there are 46 total chromosomes or 23 pairs of chromosomes: 22 autosomal and 2 sex-determining chromosomes. Humans receive half of their chromosomal makeup from their mother and half from their father. Chromosomes can be broken up into coding regions, called exons, and non-coding regions or introns. For DNA analytical purposes, analysis occurs in the non-coding regions or the introns. The coding regions will be the same inside every individual. In fact, "about $99.9 \%$ of the genome is identical between any two individuals" [4]. The coding regions are the same for every individual because these regions are transcribed and translated into proteins, enzymes and other materials needed for survival. The $.1 \%$ of the genome is where the individuals are different. It can be calculated that there are about three million sites at the $.1 \%$ of the genome that can make every individual unique, with the exception of identical twins [4]. The .1\% of the genome is made up of the non-coding regions. Analysis will occur at specific places in the non-coding regions. The areas of significance are called loci (singular: locus). A locus is a physical location on a chromosome. An example of a locus is D3S1358, a commercially used marker in DNA analysis kits. At each locus there are two specific locations or alleles. For every one locus there are two alleles. Variations of these alleles, such as different numerical sequences, lead to uniqueness of a profile.

Over the past 25 years, DNA analysis has evolved from a very slow process to a more rapid one. Dr. Jeffreys discovered variable number of tandem repeats or VNTRs. VNTRs have repeat sequences between 15 and 35 base pairs [4]. VNTRs were examined with restriction fragment length polymorphism or RFLPs [5]. RFLPs were used because the analysis "involved 
the use of a restriction enzyme to cut the regions of DNA surrounding the VNTRs" [2]. RFLPs were highly discriminating; sometimes more discriminating than current method, yet the process was very slow. The process for results was about 6 to 8 weeks and needed a significant amount of DNA sample to even consider it to be analyzed [2]. The finished product was run on a yield gel to quantify. The yield gels separate the size of the DNA fragments; small fragments will travel farther in the gel than larger fragments [4]. Larger fragments would be found higher in the yield gel while small fragments would be found lower in the yield gel. VNTRs were the first polymorphisms to be successful in analysis and in the courtrooms during the late 1980's and early 1990's [4]. The RFLP statistics were sound and was admitted into courts steadily. Shipp, et al looked at RFLP analysis after bloodstained white cotton cloths were either superglued, exposed to a high energy source light, or both [6]. They found that an RFLP profile could still be obtained after superglue fuming, but UV lighting had deleterious effects on DNA. VNTR analysis is rarely used at present time because of DNA analysis growth and advancements. As stated by Kaye, "VNTRs...does not measure the fragment lengths to the nearest number of repeats" [4]. This limitation left the examiner to estimate the number of repeats of the fragment. The analysis known as HLA DQ- $\alpha$ typing was a faster process than RFLP analysis, but results were not as discriminating as RFLP [2]. HLA DQ- $\alpha$ requires a reverse dot bot system and a colorimetric detection system where the probes were placed onto a nylon membrane and a biotin labeled product was hybridized with the probes [7]. HLA DQ- $\alpha$ typing was examined on simulated and casework envelopes, stamps and cigarette butt type evidence and questioned documents; it was determined that sufficient DNA was possible for HLA DQ- $\alpha$, even after latent print and ESDA examinations [8]. DNA analysis has evolved to the present procedures today 
through two important developments: polymerase chain reaction (PCR) and short tandem repeat (STR) analysis.

The technique of PCR analysis was conceptualized by chemist Kary Mullis in 1983 and published under the former Cetus Corporation [9]. The technique is the basis for DNA replication as millions of copies of DNA can be created in a few hours. A small sample between .5 and 2.5ng of extracted DNA is needed for optimum results [10]. The sample is placed into a specified thermal cycler and the sample is amplified, or multiplied, to create over millions of identical copies. STR analysis is the most widely used technique in today's forensic biology laboratories. STR analysis allows the examiner to observe a core repeat region that can be between 2 and 7 base pairs long and alleles correlating to the repeat region can be between 50 and 350 base pairs long $[4,10]$. Currently, biology examiners analyze four or five base pair regions with a number of different allelic markers. STR analysis can also be created to copy the areas of interest for PCR, thus decreasing the amount of DNA needed for PCR [4]. In contrast to VNTRs, STRs can determine the number of repeats found at a particular locus and it does not require a significant amount of sample to process. At a locus that is homozygous, the two alleles will have the same number of repeat sequences. At a locus that is heterozygous, the two alleles will have different number of repeat sequences. When using an analysis kit, the more loci analyzed, the more unique a profile will become.

When a crime is committed where there is bodily contact, such as homicide, assault, and rape, DNA analysis should be considered. The most common samples for DNA analysis are blood, saliva, semen, vaginal swabs and hair. DNA analysis will usually start with documentation and photography of the evidence sample. If suspicious stains are visible to the naked eye or through the use of an alternate light source, a presumptive test is applied to 
determine if the stain could be blood, semen, or any other bodily fluid. One of the most common presumptive tests for blood is the Kastle-Meyer test [11]. In this test, the stain is swabbed with a wet cotton swab. A drop of alcohol is placed onto the swab. Phenolphthalein is then added to the swab. Finally, a drop of hydrogen peroxide is added to the swab. If blood is present on the swab, the hemoglobin will react with hydrogen peroxide and the phenolphthalein will become oxidized to produce a dark pink or "permanganate" color [10,11]. Another common presumptive test is the acid phosphatase test which tests the presence of semen [12]. Acid phosphatase is found in higher concentration in seminal fluid, but can be found in other bodily fluids [12]. The stain is swabbed with a wet cotton swab. A few drops of a sodium alpha naphthylphosphate and Fast Blue B solution are added to the swab. If acid phosphatase is indicated, a purple color will be visible [2]. A definitive test for the presence of semen is the "Christmas Tree" stain test. A cutting of the swab or a clothing sample is taken and extracted. The cuttings are applied to a microscope slide. Heat is applied to fix the cells, or to not make the cells move. The "Christmas Tree stain" is then applied to the slide. The solution is made up of aluminum sulfate, nuclear fast red, picric acid, and indigo carmine. [7]. When viewed under a light microscope, the head of the sperm cell will stain a light red or pink color; the tail will stain a yellowish-green color [7]. Once it is indicated that the stain could be blood or semen, another sample is taken and extracted, either by sterile swab or cloth cutting.

The extraction method can be of the following: phenol-chloroform, DNAIQ ${ }^{\mathrm{TM}}$ Isolation System, and Chelex ${ }^{\circledR}$ 100. Of course there are several other methods available, but these methods are the most common in forensic laboratories. Phenol-chloroform dissolves the proteins in the DNA sample, and separation of the protein from DNA is possible. Phenol must be applied at least a couple of times until the protein precipitate has separated out from the aqueous solution 
[13]. The DNA can then be precipitated with a number of buffers. The one drawback to using phenol-chloroform is that it is toxic and numerous tube changes. The tube changes can cause a lower DNA concentration yield. The DNAIQ ${ }^{\mathrm{TM}}$ Isolation System is a product of Promega, Inc. and it is a safer method compared to phenol-chloroform. After extraction of the swab from the tube, silica beads are added to the solution [10]. The DNA binds to the silica beads. The solution would be placed onto a magnetic bench where the magnetic attraction leads the beads to one side. Extraction of the liquid from the solution will leave the DNA and beads. The DNA can be extracted after several steps. The Chelex ${ }^{\circledR} 100$ is a simple process as well where the solution is added to the DNA swab and incubated [14]. After incubation, Proteinase K is added to the solution. Proteinase K will digest the proteins in the solution. The solution is then centrifuged after Proteinase K has been extracted and the DNA solution is left in the test tube. It has been found that PCR is less inhibited when the Chelex ${ }^{\circledR} 100$ extraction is used [14]. If the evidence sample is seminal fluid, Proteinase $\mathrm{K}$ will not be able to break the disulphide bridges formed between the cysteine amino acids found in the acrosome of a sperm [10]. Thus, another chemical is needed to break these bridges: dithiothreitol or DTT. DTT can easily break the disulphide bridges between the cysteine amino acids and release the DNA into solution for extraction [10].

The next step in DNA analysis is quantitation. Quantitation is the process where the concentrations of the DNA samples are determined. Quantitation allows the examiner to adjust the concentrations of the DNA samples to be within range for amplification. There are various methods to determine the concentration of the samples. One early method is through the visualization of agarose gels or yield gels [10]. The gel is placed in an electrophoresis buffer and the DNA is loaded into each wells. A charge is applied across the gel and the DNA migrates 
across the gel. DNA is generally negatively charged in nature due to its phosphate groups attached to the nucleotides [10]. A negative charge is placed near the wells while a positive charge is placed at the other end of the gel. The DNA molecules will migrate to the positive side of the gel and will only migrate depending on its size in the sample. If a sample has a large concentration of DNA, then it will not travel as far as a smaller concentration of DNA. Stein (1996) used gel electrophoresis for RFLP analysis to determine a DNA profile from razor blades and glass slides after each sample was processed with cyanoacrylate, ninhydrin and gentian violet [15]. They found that "this examination showed no influence of used chemicals on DNA extraction, DNA quality, and DNA typing of samples subjected to dry storage at room temperature." Even though the process is thorough, it is very time-consuming and requires a significant amount of DNA. Forensic laboratories have been making the switch over to real time PCR. In real time PCR, one can visualize amplification as it is occurring. The instrument and quantitative analysis kit used can determine the quantity of DNA present in a sample. For example, Applied Biosystems has developed the Quantifiler analysis kit with the application of an assay known as TaqMan ${ }^{\circledR}$. Butler states that the $\operatorname{TaqMan}{ }^{\circledR}$ probe is a fluorogenic 5' nuclease assay [16]. The probes contain two fluorescent dyes: a reporter dye and a quencher dye. The reporter dye attaches to the $5^{\prime}$ end of the probe while the quencher dye attaches to the 3 ' end of the probe. The reporter dye is not able to fluoresce because it is suppressed by the quencher dye. The probe attaches to the DNA strand at a specific location between the two PCR primers. When polymerization occurs in quantitation, the probe starts to become displaced from the DNA strand. The Taq polymerase will cleave the reporter dye away from the rest of the probe, increasing the reporter dye signal [16]. Once released, the reporter dye will begin to fluoresce because it is away from the quencher dye. When more reporter dyes are released into solution, 
more PCR product has occurred [10]. Figure 1 illustrates how the TaqMan® probe works in realtime PCR. Once the quantitation results are reported, the sample may need to be concentrated or diluted to fit into the range for amplification.

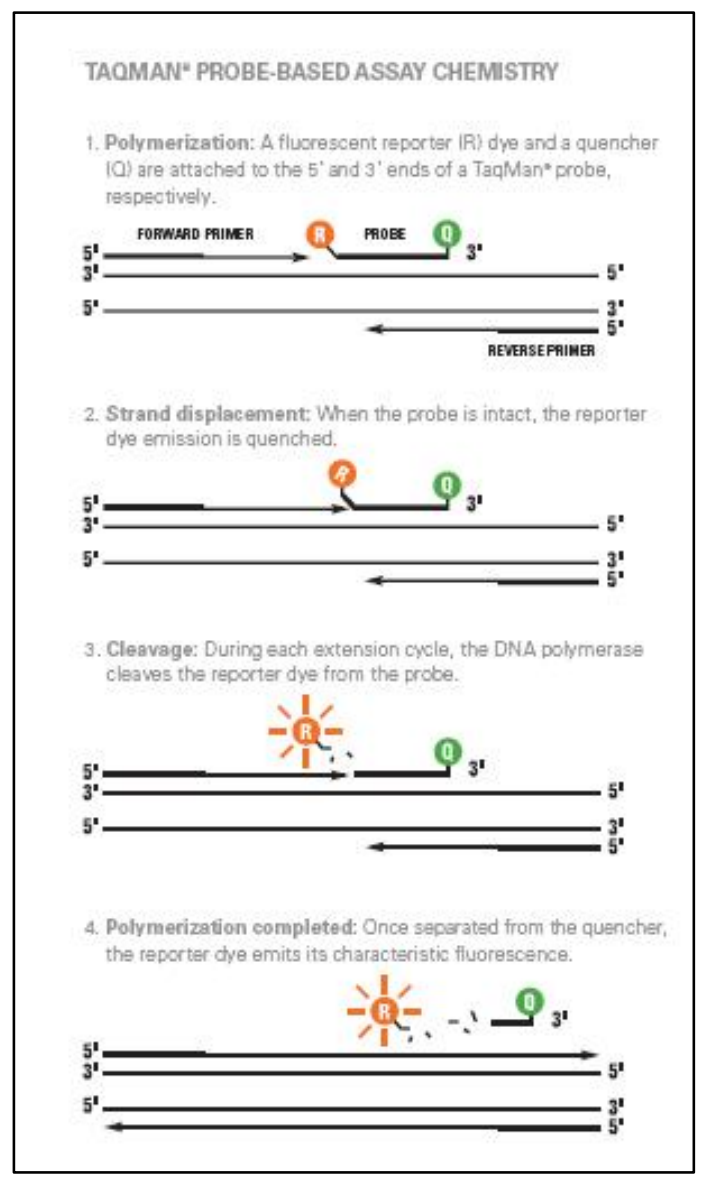

Figure 1: Overview of TaqMan ${ }^{\circledR}-$ ProbeBased Assay Chemistry (Courtesy of Life Technologies and Applied Biosystems $\left.{ }^{\mathrm{TM}}\right)$ [16].

Amplification is the process where the DNA sample is "multiplied" to an exponentially large amount. Amplification is possible with the process of polymerase chain reaction, or PCR. As stated before, PCR was conceptualized by Kary Mullis in 1983 [9]. PCR is able to focus and multiply several specific DNA regions. It also allows minute sample sizes to be amplified. PCR imitates the replication of DNA outside the nucleus of the cell. There are many components needed for PCR. These components are the DNA template, a DNA polymerase, nucleotide 
triphosphates, primers, magnesium chloride $\left(\mathrm{MgCl}_{2}\right)$, and buffers. The DNA template is the DNA of interest or target DNA strand. The DNA polymerase is the enzyme used to replicate DNA and usually the Taq Polymerase is used in this instance. The Taq Polymerase was discovered from the bacterium Thermus aquatics [9]. This certain bacterium is able to tolerate and survive high temperatures. The polymerases from Thermus aquatics do not degrade under high temperatures [9]. The nucleotide triphosphates are free standing molecules that are added to the solution. PCR will use the molecules to build copies of the original DNA template. The primers flank the region of interest and allow the Taq Polymerase to bind to the DNA template. It acts to identify the region of DNA to be amplified [2]. Magnesium chloride is used to help stabilize the process. The buffers are used to maintain $\mathrm{pH}$ and salinity balance. These components are mixed into solution to create the 'master mix' which is added to each sample for amplification.

PCR has three main steps in order to amplify DNA strands and occur in the following order: denaturation, annealing and extension. All of these steps occur at different temperatures. Denaturation occurs at $94^{\circ} \mathrm{C}$ and allows the double stranded DNA to break the hydrogen bonds that hold the double strand together [10]. For example, the two hydrogen bonds that link adenine and thymine together will break. However, the phosphodiester bonds that hold the sequence together do not break because of stronger covalent bonds. Once denaturation has occurred, the temperature will drop to the range of 50 to $60^{\circ} \mathrm{C}$ and annealing will occur [10]. The primers in solution will bind to the newly formed single-stranded DNA. Once annealing has occurred, the temperature will rise to $72^{\circ} \mathrm{C}$ and extension will start [10]. The Taq polymerase found in solution will bind to the primers and will move along the single stranded DNA placing complementary nucleotide triphosphates to the DNA. For example, the Taq polymerase will 
place a thymine in the new strand and bond it to an adenine nucleotide. The polymerase will form the hydrogen bonds between the pairs and continue on the path. The PCR mechanism would have gone through one cycle once extension has been completed. A normal PCR reaction will be between 28 and 32 cycles. After 28 cycles, there would be over 67 million copies of DNA; after 32 cycles, the number increases to over 1 billion copies [2]. Completion of amplification will allow the DNA sample to be analyzed and visualized for a DNA profile.

Analysis is the final step of DNA profiling. The analysis of a DNA sample will depend on what type of analysis kit is used and what kind of instrument separates the DNA samples into its respective peaks. A general analysis kit will look for certain DNA markers found in the sample. These markers, also called loci (singular: locus), are located at different regions on the chromosomes. Each locus has a specific name that corresponds to the location of it. For example, the locus D3S1358 is located on the short arm of the third chromosome. Each loci located in a kit will look for a set of repeating sequences and the end result will come up with a quantitative number to tell how many repeats there are at the alleles. If the specific locus is homozygous, or has the same size alleles, the number of repeat sequences will be the same. If the specific locus is heterozygous, or the alleles are different in size, then the number of repeat sequences will be different. Each kit used in analysis will have specific fluorescent dyes that will glow when it is struck by a source light [4]. In comparison to yield gels, genetic analyzers will detect the shorter fragments first and the largest fragments last.

Capillary electrophoresis, or CE, completes PCR STR analysis [17]. A buffer solution is pumped through a capillary. This buffer solution is a water-soluble polymer, such as POP-4 from Applied Biosystems. The samples are injected at specific injection times and go through the capillary. Larger DNA fragments will interact more with the medium than the smaller DNA 
fragments, thus separating the samples out $[4,17]$. The samples will pass through a fluorescent detector and an electropherogram will be produced [17]. The electropherogram will recognize allele separation at each locus, if applicable. The analysis instrument used will recognize most analysis kits through software application. In today's forensic biology labs, there are over a dozen DNA analysis kits. The most common kits used in laboratories are created by Applied Biosystems or Promega. Applied Biosystems have created the kits named AmpFlSTR®. There are different variations, such as Profiler ${ }^{\mathrm{TM}}$, Profiler Plus ${ }^{\mathrm{TM}}$, and Identifiler ${ }^{\mathrm{TM}}$ [18]. Promega has created kits named PowerPlex ${ }^{\circledR}$ and some variations include PowerPlex ${ }^{\circledR} 16$, PowerPlex ${ }^{\circledR}$ 2.1, and PowerPlex® HS [19]. Each aforementioned kit does have a slight variance to it; different loci may be analyzed. No matter which kit is used, the same kit will be used to process all DNA samples in one particular lab.

In 1994 the United States passed the DNA Identification Act. This act allowed the establishment of the Combined DNA Index System or CODIS in 1998 by the Federal Bureau of Investigation (FBI) [20]. CODIS is a federally held DNA database; it allows the federal, state and local laboratories to link DNA profiles and has expanded over the last 15 years [20]. When a person's information is loaded into CODIS, it can contain a laboratory identifier, a specimen finder, the DNA profile and the integrity of the DNA record [10]. CODIS uses 13 STR loci for the national DNA database. The 13 STR loci are the following: CSF1PO, FGA, TH01, TPOX, VWA, D3S1358, D5S818, D7S820, D8S1179, D13S317, D16S539, D18S51, D21S11, and Amelogenin, the gender determining gene [2]. STR analysis from all laboratories allows CODIS to be a powerful tool for missing person profiles or for developing a suspect. As the FBI states, "Based upon a match, police from multiple jurisdictions can coordinate their respective 
investigations and share the leads they developed independently" [20]. The kits developed by Applied Biosystems and Promega contain these 13 core loci.

In the $21^{\text {st }}$ century, forensic biology examiners have been focusing research on making DNA analysis more sensitive by decreasing the amount of DNA sample needed for analysis. Generally, examiners only need between .5 and 2ng of DNA to analyze [10]. However, low template number DNA (LTDNA) testing is found to be less than .1ng or 100pg (picograms) [21, 22]. Newer instruments have been created to detect more sensitive and lower amounts of DNA. Examples of such low amounts of DNA are in fingerprints, skin (or epithelial) cells, and secondary transfer. Low amounts of DNA can be found on anything that has been touched by an individual. Low template DNA is essentially the same analysis as normal PCR STR analysis, but there are a few modifications. The cycle number for DNA amplification can be increased from a normal amount of 28 cycles to a maximum of 34 cycles. Kloosterman (2003) determined and validated the application of 34 cycles should be used when normal PCR conditions cannot create a DNA profile [23]. Multiple amplifications of the same sample should occur. Samples should be run in triplicate, or run on the same amplification three times [21, 24, 25]. This increases the chance of confirming an allele to be present in a profile and eliminate alleles that appear in one sample. Negative controls should be used with every analytical test [24]. Van Oorschot (2003) has also suggested that through improved collection, extraction and quantitation techniques, more available trace amounts of DNA can be obtained [26].

There are some drawbacks to low template DNA analysis. With the increased sensitivity of amplification, the sample could start to develop stochastic effects. Stochastic effects are not the analyst's fault; they occur in amplification from improper or lack of annealing and extension. The most common forms of stochastic effects are heterozygote imbalance, allele drop-out, allele 
drop-in, stutter peaks, and near threshold peaks [21, 27, 28]. Several authors and researchers have found stochastic effects inevitable because the small amount of DNA available for amplification increases the risk. Heterozygote imbalances are not as significant as allele dropouts or drop-ins. Cowen (2011) states that a heterozygote imbalance occurs when the distribution of the ratio of peak areas is increased and one allele peak is significantly larger than the other allele peak [28]. However, both peaks are still present and a proper conclusion can still occur. Allele drop-outs occur when an allele area peak is not higher than the threshold level [28]. The allele is not absent in the template DNA, but is hidden in the background noise located beneath the threshold level or missed entirely during the first rounds of amplification [27]. An examiner could decrease the relative fluorescent units (RFU) to increase the possibility of observing the allele. An allele could also not amplify at all and not be observed; this is called an extreme allele drop-out. Allele drop-ins will also occur. These alleles are not represented by the profile of the donor [28]. Extraneous or contaminated DNA could be amplified and be observed in the profile. Stutter peaks are the most common stochastic effects. They arise during PCR because of strand slippage. This means that the strands are typically $4 \mathrm{bp}$ shorter than the main alleles. Sometimes, stutter peaks can occur larger than they really are. This proves that although increasing sensitivity would be beneficial for more profiles to be recovered, it also increases risk of stochastic effects in the sample. Low template DNA analysis should not be on the same level of analysis as conventional DNA analysis. It should be noted as well that since low template DNA analysis is more sensitive than conventional DNA analysis, the stochastic threshold must also change [29]. Puch-Solis used statistical data called the "tail method" to determine the change in the stochastic threshold. The equation is: 
where $p_{1}$ represents the proportion of heights smaller than $50 \mathrm{RFU}$ out of all heights of heterozygotes, $p_{2}$ represents the proportion of alleles whose heights are greater than a cut-off point $\mathrm{C}$ out all alleles where the partner allele has a height smaller than $50 \mathrm{RFU}$ and $p_{3}$ represents the probability that a height of an allele is greater than $\mathrm{T}$ out of all heights greater than cut-off point $\mathrm{C}$ and whose partner allele has a height smaller than $50 \mathrm{RFU}$ [29].

Fortunately, researchers have been able to determine that touch DNA is able to be analyzed. Van Oorschot and Jones (1997) reported that they were able to correctly obtain DNA profiles and yield DNA samples from 2 to $150 \mathrm{ng}$ from swabs directly taken from the palm of a hand [30]. The examiners also produced profiles of multiple alleles of various intensities from different objects [30]. Findlay and Frazier (1997) used Oorschot's results and tested it against six forensic STR markers [31]. They did not state what STR markers were used in analysis, but did find favorable results after micromanipulation procedures and 34 cycles of amplification [31]. Renterghem (2000) was able to develop a full DNA profile from fingerprints placed on a microscope slide with no application of processes [32].

Gill (2000) found full profiles when the PCR step was set to 34 cycles while using the AMPFlSTR ${ }^{\circledR}$ SGM Plus ${ }^{\mathrm{TM}}$ analysis kit [21]. He stated that the amount that can be fully profiled is from 25-50pg, or 4 to 10 cell nuclei. He also stated the Taq polymerase enzyme used in amplification becomes inefficient above 34 cycles. Finally, he also stated that one cannot get any profiles when the DNA sample contains less than 25pg [21]. Wickenheiser (2002) determined that some surfaces are able to hold more DNA bearing cells than other surfaces [22]. He stated that "epithelial cells sloughed through active handling onto a porous and jagged substrate should comprise a good portion of the DNA yielding cells [22]. He also stated that 
surfaces that do not develop good fingerprints will obtain a better DNA profile while surfaces that do develop good fingerprints after processing do not develop a DNA profile [22].

Several researchers have modified various parts of the amplification and analysis processes. Caragine and company (2009) used protocols and interpretation guidelines to validate low template DNA testing for AmpFlSTR ${ }^{\circledR}$ Identifiler® [33]. The samples were amplified in triplicate under enhanced PCR conditions to produce "robust and reliable" results. They created quality control, testing, and interpretation protocols [33]. Weiler (2012) concluded that it is possible to improve DNA recovery by increasing the annealing time during amplification [27]. Even though the entire PCR process was increased to 10 hours, the process does not require hands-on tweaking and can be included in the PCR process. It has shown less allelic drop-outs and increased peak heights compared to the conventional DNA amplification [27]. Davis (2011) included proofreading enzymes to the PCR master mix to improve DNA recovery and profiling [34]. Proofreading enzymes would edit and replace the correct bases the Taq Polymerase mistakenly placed during extension. However, they discovered that adding a proofreading enzyme did not improve STR results for such a low amount of DNA. They also recommended not to use proofreading enzymes for low template DNA work [34].

Fingerprints are impressions of a person's dermal ridges placed onto a surface or substrate. This substrate can range from glass to wood to metal. A fingerprint is deposited onto a surface from the perspiration and oils that are secreted from the skin. The sweat and oils can also contain DNA bearing cells and can be used for analysis [22]. A fingerprint can be found as a visible print or as a latent print. A visible print is a print that is observed with the naked eye without any assistance from detection techniques. A latent print is invisible to the naked eye and requires some assistance from detection techniques. Fingerprint examination is a very important 
area of forensic science; it was at one time the only identification method before DNA was used for forensic purposes.

The examination is based on two main principles. The first fingerprint principle is that the fingerprint is persistent [35]. Dermal ridges are formed on the fetus's fingerprint around the $10^{\text {th }}$ to $16^{\text {th }}$ week of gestation [36]. There has been some research done to determine if certain genes located in the genome can slightly cause dermal ridge development [37]. However, more research is needed to confirm this. Once the dermal ridges are formed on the fingers of the fetus, the dermal ridges are permanent and remain unchanged for the duration of the individual's life [36]. The only way the individual can change his or her fingerprint is if an injury cuts deep into the dermal layer and a scar is formed.

The second fingerprint principle is that a fingerprint is unique [35]. There are three general classifications of fingerprints: arches, loops and whorls. In addition to the general classifications, a fingerprint will have several different ridge characteristics, or minutiae. These ridge characteristics can include ridge endings, bifurcations, and enclosures. When looking even deeper at fingerprint, a fingerprint's ridges and pores could potentially be present. The combination of the general classifications, the position of the ridge characteristics, and the shape of the ridges and pores will make a fingerprint unique.

A fingerprint, whether a visible or latent print, will have a different appearance on various surfaces. There are two general classifications of surfaces: porous and non-porous. Porous surfaces will include wood, paper, cardboard and fibers (cloths). Porous surfaces will "hold" the fingerprint on top of its surface for a short amount of time. Eventually, some of the substances in the fingerprint will be absorbed by the surface, leaving a residue. The fingerprint 
could be difficult to develop for fingerprint examination, but it could be extremely useful for DNA analysis. Non-porous surfaces will include glass, tile, ceramic, metal, and plastic. Unlike porous surfaces, non-porous surfaces will have the fingerprint residues stay on top of the surface for a significantly longer time. There are other classifications of surfaces, such as semi-porous and soft prints (which could include putty, soap and wax), but these surfaces have not been researched in depth as the two main surfaces.

When a fingerprint is suspected to be on a particular surface during a crime scene investigation, the examiner will document the print with notes and photography, recover the evidence, if possible, and return it to the laboratory for development. The examiner will choose a fingerprint detection technique depending on the surface. Of course, there are different fingerprint detection techniques for porous and non-porous surfaces.

Fingerprint detection techniques for porous surfaces include iodine fuming, physical developer, silver nitrate, ninhydrin and 1,8 diazafluoren-9-one or DFO. Iodine fuming occurs when crystalline iodine, when heated, is sublimed. Latent prints are developed with iodine when the item of interest is placed into an enclosed area and gaseous iodine is produced [38]. The fingerprints will interact with the iodine molecules and will produce a purple print. However, this purple print will disappear over time, so processing and photography must be quick. Physical developer is used when other porous surface processes have not developed a sufficient fingerprint. Physical developer can also be used for a fingerprint that was once wet [38]. However, physical developer will wash away any proteins that were part of the fingerprint. This could have deleterious effects on DNA Analysis. Silver nitrate is also used on porous surfaces. When applied, the silver nitrate reacts with the sodium chloride, or salt content, in the fingerprint residues [38]. 
Ninhydrin was first introduced as a fingerprint reagent for porous surfaces in 1954 [39]. Ninhydrin is another porous surface process where the chemicals of ninhydrin react with the amino acids that are in the fingerprint. This reaction will form a blue-purple fingerprint color called Ruhemann's Purple [38,39]. Ninhydrin has become one of the most popular choices for fingerprint development on paper. Items of interest are dipped into a ninhydrin solution and left to dry for 24 to 48 hours [39]. The process of ninhydrin can be accelerated with the application of heat; the simplest method is with an iron. A ninhydrin chamber can be used where temperature and moisture are set for a certain amount of time [39]. DFO, available in 1990, is a more sensitive process for porous surfaces where it has replaced ninhydrin in some cases [39]. The fingerprint is developed by reacting to the amino acids in the fingerprint residues on dry porous surfaces $[39,40]$. The finished product of DFO needs heat and the fingerprint is observed using a specialized light source. DFO was used in research for potential threat mail before being used for DNA analysis [40]. They did find that DFO did not interfere with DNA analysis and a successful DNA profile could be obtained.

Fingerprint detection techniques for non-porous surfaces include powders, cyanoacrylate or superglue, gentian violet and amido black. The most common application of non-porous surfaces is powders. There are various powders: black, fluorescent, and magnetic. Black powder is the most traditional powder where a camel hair or fiberglass brush is dabbed into the container and gently dusted onto the fingerprint [38]. Black powder works most effectively when applied to white or light colored surfaces. Fluorescent powders are bright colored powders that are applied to the surface the same method as black powder, but require an alternate light source to see a detailed fingerprint. Again, some alternate light sources can degrade DNA and have an impact in DNA analysis. Different colored powders work most effectively at different 
wavelengths. Magnetic powder is applied like black and fluorescent powder, but the magnetic brush is a wand with no bristles [38]. The wand is magnetized to attract iron fillings along with other fillers and it is passed over the fingerprint. Some of the fillings will adhere to the print, leaving the impression. This reduces damage or destruction to the fingerprint. Research has been specifically done with powders on fingerprints to determine if a DNA profile can be produced [41]. Eleven powders ranging from white powders, black powders and magnetic powders were used on fingerprints that were deposited on glass and wooden plates. They found that the DNA peak heights for glass were lower than for wood. They also found that application of a brush can potentially wipe away any DNA material on the surface. Finally, it was shown that five powders were useful and did not interfere with DNA analysis; of particular interest was magnetic powder [41].

Cyanoacrylate, or superglue, fuming is a popular method for processing fingerprints on most non-porous surfaces. The chemical is mostly cyanoacrylate ester and it interacts with the residues in the fingerprint $[38,39]$. The fumes of superglue can be applied by the application of heat. Superglue fuming chambers are typically designed to process multiple items. A heat plate and a small volume of superglue are added to the chamber and the reaction takes place. The end product will have a white-colored fingerprint. Zamir used cyanoacrylate fuming for the enhancement of fingerprints on adhesive tape and then processed for DNA profiles [42]. The results showed that cyanoacrylate fuming or the fingerprint processes after it did not interfere with DNA analysis. Gentian violet is a process that develops prints on the adhesive side of tape [38]. When the application is applied, the print will become purple in color. Amido black develops prints that have been placed in blood or bloodstains [38]. It is sprayed on the print to 
develop the ridges; then a rinsing with tap water washes away the residues that are not associated with the print.

Research has been performed as to whether these fingerprint detection processes affect DNA analysis. One of the earliest research articles written by Shipp used argon light lasers, alternate light sources and superglue on bloodstains [6]. RFLP analysis was done after the application of one of the three processes. They found that no effects to the DNA sample while using superglue or a laser, but had some deleterious effects on DNA while using the alternate light source, especially UV [6]. However, one has to remember that the DNA process done in this research was RFLP analysis which is rarely done in laboratories anymore. Alternate light sources were observed on thin bloodsmears to determine if these sources deteriorate DNA [43]. The examiners used four different light sources: argon-ion laser, a Polilight, a Superlite, and a shortwave UV source. After PCR amplification, it was found that shortwave UV light should be avoided because it degraded the DNA samples. However, the other three light sources used did not have any effect on PCR-STR analysis [43]. In other research fingerprints were deposited in blood and processed on paper, glass, bags, tape, and steel blades while using the processes of UV light, DFO, physical developer, ninhydrin and cadmium, luminol, cyanoacrylate, gentian violet, powders, multimetal deposition (MMD), and amido black [44]. They used aged bloodstains (1 week, 1 month, and 3 months) with the fingerprint processes and it was determined that the only processes not to use for DNA analysis were MMD, UV radiation, and magnetic powder[44]. This is contradictory to what was found from Van Hoofstat [41] because he found that magnetic powders do not interfere with DNA analysis. Another study was used to determine if magnetic powder, along with soot powder and scotch tape inhibit DNA profile production [45]. It was 
determined that there was a small amount of DNA present after extraction and quantitation $(<.01$ to $.3 \mathrm{ng}$ ) and only some fingerprints created DNA profiles.

Some researchers have focused on obtaining low template DNA profiles from various surfaces. Pesaresi (2003) applied fingerprints to glass, metal, and wood by preparing them through pressure for 30 seconds or rolling them [46]. Fingerprint powders were sprinkled onto the samples. Favorable results were found as DNA profiles could be obtained after analysis. The most favorable conditions were with metal surfaces [46]. Alessandrini (2003) also attempted to develop DNA profiles from glass, metal and wood [47]. They tested a total of 374 samples and discovered that the amount of DNA recovered can vary in different experiments from the same donor. This amount ranged from no DNA to tens or hundreds of picograms. They did determine that the quantity of DNA recovered depends on two factors: 1) the amount of DNA left by touching objects and 2) the suitability of recovery and extraction techniques [47]. Daly (2011) concludes that wood surfaces will have a greater chance of recovering a DNA than fabric surfaces or glass surfaces [48]. The article also stated that any low level DNA quantification result of less than $.03 \mathrm{ng} / \mu \mathrm{L}$ should not be amplified. This means that any sample that has an amount of less than 30 pg of DNA should not be amplified [48]. An uncommon surface to swab for and obtain a sufficient DNA profile is from firearms and fired cartridge cases [49].

Raymond (2004) used five surfaces for their research: aluminum foil, polyethylene bags, paper, clear glass, and adhesive tape [50]. The fingerprint processes they used were UV light, DFO, ninhydrin, ninhydrin with a zinc metal salt treatment, white light, white powder, black powder, magnetic powder, cyanoacrylate (alone and with rhodamine $6 \mathrm{G}$ and vacuum metal deposition), stickyside powder, amido black, luminol, and diamino-benzidine (DAB). Each 
surface was washed with ethanol before a print was applied. The subject placed a fingerprint on the surface for 30 seconds and each surface was left untouched for two days. Amplification used was the AMPFlSTR Profiler Plus running on 34 cycles. They found that DNA profiles were obtained on microscope slides, plastic bags and tape before and after fingerprint processing, but found that paper and foil had less success [50]. They also state three factors that could have affected a significantly low success rate:

- "The amount of liquid left in the microcon after the extraction process was much greater for the paper samples than for any other surface...resulting in the template DNA being more dilute.” [50]

- "A large surface area of the paper was covered, which then needed to be fit in the incubation tube. Given these cramped conditions, the chelex may not have come into contact with all of the skin debris."'[50]

- "Bleach and other whitening agents used in the manufacture of the paper may have interacted with the DNA during incubation.’[50]

It is stated by Kanable (2005) that "when fingerprints are subjected to chemical fingerprint processing before DNA profiling, Ramotowski says the amount of DNA is diminished further" [51]. Even though this is true, DNA analysis after fingerprint process application is still possible. She also states that ninhydrin, DFO, black powder and white powder do not interfere with DNA typing [51]. This is confirmed from several researches in the past [40, 41, 52]. Raymond states numerous fingerprint processes and their effect on DNA analysis [53]. This research is focused on ninhydrin and DFO, so these two reagents will only be discussed from the article. Both ninhydrin and DFO will reduce the amount of DNA quantitated, but it will not significantly affect the recovery of DNA profiles [53]. 
Other researchers have focused on determining DNA profiles after the application of ninhydrin and DFO on fingerprints. Schulz (2004) placed DNA probes on cellulose, dried the probes, and then applied ninhydrin spray [52]. The group also tested for DNA profiles by using ninhydrin-dyed fingerprints found on wallpaper. The DNA probes were extracted and quantitated using a TaqMan® probe (Applied Biosystems) during real-time PCR while the ninhydrin-dyed prints were amplified. Even though the DNA samples were smaller in amount than normal, it was found that the ninhydrin did not interfere with DNA analysis in either the probes or the ninhydrin-dyed prints, [52]. In a study, 285 swabs were taken from crime scenes and stained with ninhydrin [54]. The swabs were then analyzed for DNA profiles. It was found that out of 285 samples treated with ninhydrin, 158 developed a purple color. Out of those swabs, 120 (76\%) yielded a DNA profile suitable for the German national DNA database. It was concluded that ninhydrin could be used as a DNA screening method, but only for less serious crimes [54]. This study confirms that ninhydrin does not completely inhibit DNA analysis, but only reduce the amount of DNA recovered.

The research conducted by Grubwieser, et al. focused on recovering DNA profiles from a number of blood, saliva and finger mark samples [55]. They used various fingerprint detection techniques, including ninhydrin and DFO. They found that ninhydrin had no adverse effects on DNA amplification. For DFO, however, they found the shorter the incubation time, the better the recovery. Their efforts for DFO were to determine if absolute temperature or incubation time led to a reduction of recovery [55]. After testing samples for 60 minutes at $60^{\circ} \mathrm{C}$ and for 15 minutes at $100^{\circ} \mathrm{C}$, they concluded that longer incubation time rather than absolute temperature affected the samples and recovery more [55]. Bhoelai (2011) found that the risk of DNA contamination should be taken into effect when fingerprint reagents are used before analysis 
[56]. The samples were processed for fingerprints, such as cyanoacrylate fuming, ninhydrin and DFO, and then they were processed for DNA analysis. It was determined that even though ninhydrin or DFO did not affect DNA analysis, some samples showed contamination and it has been recommended that fresh solutions are made before immersion [56].

Few researchers have attempted to develop DNA profiles from fingerprints deposited on paper. Balogh and company (2003) extracted DNA after pieces of paper were handled by volunteers [57]. After trying four different extraction methods on paper, the samples were amplified and analyzed. It was found that phenol/chloroform extraction yielded only $10 \%$ of deposited DNA, but DNA profiles are able to be obtained after analysis [57]. Sewell and company tested a number of various papers for DNA analysis after the application of either ninhydrin or DFO [58]. Prints were placed down on four types of paper and sealed in plastic evidence bags at $4^{\circ} \mathrm{C}$. Some fingerprints were developed with DFO, ninhydrin, or both. The samples were extracted with DNeasy® Plant Mini Kit, concentrated and quantitated using Quantifiler®. The samples with the highest DNA concentration was amplified using AmpFlSTR® SGM plus ${ }^{\mathrm{TM}}$ amplification kit at 28 cycles. They reported that magazine paper recovered the most DNA while office paper recovered the least. They also found no profiles for untreated fingerprints deposited on office paper after 28 cycles. However, an increase of profile presence was noted when the cycles were increased from 28 to 34 . They stated that the samples will be reduced in recovered DNA if treated with ninhydrin or DFO [58]. Lastly, they stated that the amount of DNA deposited on paper can vary and contribute a significant part in the development of profiles.

Balogh (2003) deposited fingerprints on small cuttings of white paper during several various environmental methods: touching periods, delay, time of day, swab experiment, after 
enhancement, and mixture experiment [59]. Their results only showed percentages of profile recovery, but they concluded that the touching periods, delay, and time of day experiments provided strong partial to full profiles while the after enhancement experiment showed the least favorable results. They suggested increasing the cycle numbers to 38 to increase sensitivity, but also introduces more stochastic effects [59].

The majority of the articles are dated because the instrumentation, extraction methods, quantitation, amplification, or analysis is no longer used in forensic laboratories. Extraction methods that were once too long or too tedious are now obsolete. Quantitation, such as using a yield gel or a slot blot, is now being replaced by real time PCR. Older amplification methods, such as RFLP and HLA-DQ $\alpha$, are no longer used because of the amount of DNA needed for each process to work.

\section{Materials/Methods}

It is important to note that proper protective equipment was worn during all extractions, quantitations, amplifications and analyses. The bench and pipets were cleaned with $10 \%$ bleach solution and had an ultraviolet light on for fifteen minutes before and after each process.

\section{Phase I- Initial determination of DNA profiles}

\section{Extraction}

Commercial office paper was bought at a local retail store. The type of paper used was International Paper Hammermill@ Copy Plus Item number 105090. The paper brightness, which is the degree to which paper reflects light, was 92. For the first phase of the research, two 
different processes occurred: (1) both hands were placed on separate papers simultaneously and (2) one finger (right index finger) was placed down for a span of one to two seconds ten consecutive times. Boxes were created on the paper with a black sharpie marker for the purpose of placing fingers down inside them. The boxes for the first process were marked from numbers one to ten, starting with the right thumb as number one and ending with the left little finger as number ten. The boxes for the second process were marked from one to ten and the right index finger was placed consecutively. Once the fingerprints were placed in the boxes, small samples measuring approximately $2 \mathrm{~cm}$ by $1 \mathrm{~cm}$ from inside the box were cut out with a clean scalpel. The scalpel was cleaned with $10 \%$ bleach solution before each cut. The samples were placed into individually marked $1.5 \mathrm{~mL}$ microcentrifuge tubes. The two processes were done three times for a total of sixty samples in Phase I. Cheeks were swabbed with clean sterile cotton swabs. These swabs were the positive reagents. Two negative controls were also included in the research. The positive reagents came from the left cheek while there was no sample for the negative control.

Each sample went through a phenol-chloroform extraction underneath a hood. The phenol-chloroform extraction method was performed under the same guidelines of the West Virginia State Police DNA Analysis Laboratory. 500 $\mu \mathrm{L}$ of digest buffer and $15 \mu \mathrm{L}$ of Proteinase $\mathrm{K}$ was pipetted into each sample. The samples were vortexed and placed into a water bath set at $56^{\circ} \mathrm{C}$ for digestion. The samples were incubated overnight but never past 24 hours. After digestion, the samples were taken out of solution and placed into a spin basket tube. 
The samples were centrifuged for five to ten seconds to extract all possible DNA. The samples and spin baskets were discarded into a biohazard bag. Half of the samples (\#21-50) were placed into a refrigerator at that point for an extended period. Once the samples were ready for extraction, $500 \mu \mathrm{L}$ of phenol-chloroform was pipetted into each sample. The samples were vortexed and centrifuged at $15,000 * \mathrm{~g}$ for two minutes. New microcentrifuge tubes were marked and the top aqueous layer was pipetted from the old solution to the new tubes. The used

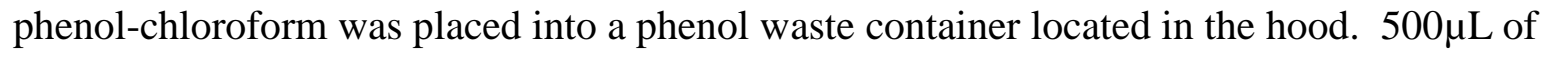
phenol-chloroform was pipetted into the samples; the samples were vortexed and centrifuged at the same settings. The same procedure was repeated again for a total of three times.

Amicon Ultra-.5mL centrifugal filter units, or Microcon units, were assembled and labeled for respective samples. $100 \mu \mathrm{L}$ of distilled water was placed into the concentrators. The top aqueous layer from the phenol-chloroform extraction was pipetted from there into the concentrators. The samples were centrifuged at 3,000* $\mathrm{g}$ for five minutes. The filtered waste was discarded into a separate tube. $400 \mu \mathrm{L}$ of hot distilled water was pipetted into each sample. The samples were centrifuged at $4,000 * \mathrm{~g}$ for five minutes. The test tubes were discarded and $60 \mu \mathrm{L}$ of distilled water was pipetted into the concentrator. A new tube was added to each concentrator and the samples were briefly vortexed. The samples were inverted and centrifuged at $10,000 * \mathrm{~g}$ for three minutes. The concentrators were discarded and the micro test tubes were stored in a labeled box in the freezer. 


\section{Quantitation}

Samples were retrieved from the freezer and allowed to thaw. For quantitation, the procedure was the same of the West Virginia State Police DNA Laboratory. Several processes needed to be completed before the samples could be quantitated. The standard stock solution was obtained from the Quantifiler ${ }^{\mathrm{TM}}$ Human DNA Quantification Kit (Applied Biosystems); the standards needed to be created and diluted. Table 1 shows how the standards were prepared. A quantitation worksheet needed to be created. A quantitation master mix was created for every set of quantitations. Equation 1 determines the amount of master mix needed to be created.

Table 1: Creation of Standard Concentrations for Quantitation

\begin{tabular}{|c|c|c|c|}
\hline Quant Std. \# & Amount/Description & TE buffer amount $(\mu \mathrm{L})$ & {$[$ Standard] $(\mathrm{ng} / \mu \mathrm{L})$} \\
\hline 1 & $10 \mu \mathrm{L}$ of $200 \mathrm{ng} / \mathrm{uL}$ stock solution & 30 & 50.0 \\
\hline 2 & $10 \mu \mathrm{L}$ from Std. 1 & 20 & 16.7 \\
\hline 3 & $10 \mu \mathrm{L}$ from Std. 2 & 20 & 5.56 \\
\hline 4 & $10 \mu \mathrm{L}$ from Std. 3 & 20 & .85 \\
\hline 5 & $10 \mu \mathrm{L}$ from Std. 4 & 20 & .620 \\
\hline 6 & $10 \mu \mathrm{L}$ from Std. 5 & 20 & .0680 \\
\hline 7 & $10 \mu \mathrm{L}$ from Std. 6 & 20 & .0230 \\
\hline 8 & $10 \mu \mathrm{L}$ from Std. 7 & 20 & \\
\hline
\end{tabular}

Equation 1: Determination of the amount of master mix needed for quantitation

\# samples currently +2 rows of standards $(16)+2$ for error $=$ total samples PCR Reaction Mix: total \# samples x $12.5 \mu \mathrm{L}=$ total amount of Reaction mix

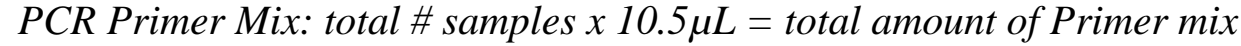

$23 \mu \mathrm{L}$ of the master mix is pipetted into individual wells. $2 \mu \mathrm{L}$ of each sample was pipetted into the respective wells. Flat-top lids were placed on the rows which were then centrifuged for twenty seconds before being placed into the quantitation instrumentation. The instrument used for quantitation was the ABI Prism 7500 Real Time PCR (Applied Biosystems) and the software 
for the instrument was the 7500 SDS Software v.1.2. A SDS document was created for each quantitation run. The results were observed and recorded.

\section{Amplification}

Phase I samples were amplified using the manufacture recommended guidelines. Samples were taken out of the freezer and allowed to thaw. The target value for amplification using the AmpFlSTR® Identifiler® kit is $.05 \mathrm{ng} / \mu \mathrm{L}$ to $.125 \mathrm{ng} / \mu \mathrm{L}$. Most samples were below the target value of $.125 \mathrm{ng} / \mu \mathrm{L}$. Therefore, no dilution was needed. The amount of master mix needed to be calculated. Equation 2 illustrates how the Identifiler® master mix was prepared.

\section{Equation 2: Calculation of Amplification Master Mix for AMPFISTR ${ }^{\circledR}$ Identifiler ${ }^{\circledR}$}

\# samples + positive control + negative control + 1 sample extra for error $=$ total samples AmpFISTR PCR Reaction Mix: total samples $x 10.5 \mu \mathrm{L}=$ total amount of PCR reaction mix AmpliTaq Gold DNA Polymerase: total samples $x .5 \mu L=$ total amount of DNA polymerase AmpFISTR Identifiler Primer Set: total samples $x 5.5 \mu \mathrm{L}=$ total amout of primer

After the master mix was created, it was vortexed. $15 \mu \mathrm{L}$ of the master mix was dispensed into individually labeled PCR tubes. $10 \mu \mathrm{L}$ of the samples was pipetted into its respective PCR tubes. Rounded caps were placed on the rows when finished. The positive control was supplied with the Identifiler ${ }^{\circledR}$ Amplification Kit labeled the AmpFlSTR® Control DNA 9947A tube (.10ng/ $\mu \mathrm{L})$ while the negative control was TE buffer. The samples were placed into the GeneAmp® ThermoCycler PCR System 9700 (Applied Biosystems) and set to Identifiler® run setup. The parameters for the Identifiler ${ }^{\circledR}$ are described below in Table 2. After its run, the tubes were placed in a freezer stored in the amplification laboratory until analysis. 
Table 2: Parameters for the Identifiler ${ }^{\circledR}$ LCN Profile Run Setup on the ThermoCycler PCR System 9700

\begin{tabular}{|c|c|c|c|c|c|}
\hline $\begin{array}{c}\text { Initial } \\
\text { Incubation } \\
\text { Setup }\end{array}$ & Denature & Anneal & Extend & $\begin{array}{c}\text { Final } \\
\text { Extension }\end{array}$ & Final Step \\
\hline HOLD & \multicolumn{2}{|c|}{ CYCLE $(28$ cycles $)$} & HOLD & HOLD \\
\hline $95^{\circ} \mathrm{C}$ & $94^{\circ} \mathrm{C}$ & $59^{\circ} \mathrm{C}$ & $72^{\circ} \mathrm{C}$ & $60^{\circ} \mathrm{C}$ & $4^{\circ} \mathrm{C}$ \\
\hline $11 \mathrm{~min}$ & $1 \mathrm{~min}$ & $1 \mathrm{~min}$ & $1 \mathrm{~min}$ & $60 \mathrm{~min}$ & (forever) \\
\hline
\end{tabular}

Analysis

Equation 3: Calculation of the analysis solution (Hi-Di ${ }^{\mathrm{TM}}$ Formamide/GeneScan ${ }^{\mathrm{TM}}-500$

\section{LIZTM Size Standard)}

\# samples + one AmpFISTR $\mathbb{R}$ Identifiler ${ }^{\mathrm{TM}}$ Allelic Ladder for every ten samples $H i$-Di ${ }^{\mathrm{TM}}$ Formamide: (number of samples +2 ) $\times 24.5 \mu \mathrm{L}=$ total amount of formamide GeneScan ${ }^{\mathrm{TM}}-500$ LIZ ${ }^{\mathrm{TM}}$ Size Standard: (number of samples +2$) x .5 \mu L=$ total amount of standard

The guidelines for setup are the same from the recommended manufacturer guidelines. Equation 3 illustrates how the Hi-Di ${ }^{\mathrm{TM}}$ Formamide/GeneScan ${ }^{\mathrm{TM}}-500$ LIZ ${ }^{\mathrm{TM}}$ Size Standard solutions is calculated. The solution was vortexed and centrifuged. The samples from amplification were taken out of the amplification laboratory freezer. The number of allelic ladders was determined. $25 \mu \mathrm{L}$ of the standard solution was pipetted into new PCR tubes. $1.5 \mu \mathrm{L}$ of each sample, allelic ladder, control and reagent was pipetted into its respective tubes. Each tube was mixed by pipetting the solution up and down. The tubes were sealed with a septum, vortexed, and centrifuged. The samples were denatured for three minutes at $95^{\circ} \mathrm{C}$ in the GeneAmp® ThermoCycler PCR System 9700 instrument, and then chilled for three minutes in the amplification laboratory freezer. The samples were placed on a prepared ABI 3130 Genetic Analyzer (Applied Biosystems). Results were observed and recorded. 


\section{Phase II-Recovery of DNA Profiles given Time Periods}

Time intervals were determined for Phase II. These time intervals are the following: $1 \mathrm{hr}$, $2 \mathrm{hr}, 3 \mathrm{hr}, 6 \mathrm{hr}, 12 \mathrm{hr}, 24 \mathrm{hr}, 36 \mathrm{hr}, 48 \mathrm{hr}, 72 \mathrm{hr}, 96 \mathrm{hr}$, and $120 \mathrm{hr}$. Eleven sheets of paper were given certain time intervals. Five boxes were created on the sheets of paper to place the fingerprints on. The numbering is similar to the phase I samples; the first sample is the right thumb and the last sample is the right little finger. Eleven sheets of paper with five samples on each paper totals fifty-five total samples for Phase II. The right hand was placed on each paper, but not consecutively. The hand was rubbed either through hair, with both hands or from the skin. When the time interval was complete, the samples were cut with a clean scalpel. A positive reagent (buccal swab from the right cheek) and a negative control were created. The samples would go through the same process for extraction, quantitation, amplification and analysis. Selected samples were amplified using the AMPFlSTR $®$ Identifiler® amplification kit and the low copy number (LCN) parameters for the Thermocycler. The difference between the LCN and normal parameters is the addition of 3 cycles for a total of 31 cycles.

\section{Phase III - Recovery of DNA Profiles given the Application of Ninhydrin or DFO given Certain Time Periods}

The procedure from Phase II was used in Phase III with two exceptions. First, the paper was cut in half. One half of the paper was dipped in a bath of pre-mixed Ninhydrin solution. The paper was allowed to air dry before observation. The other half of the paper was sprayed with pre-mixed DFO solution and allowed to air dry. DFO treated paper was placed in $100^{\circ} \mathrm{C}$ dry oven for twenty minutes as recommended by the FBI. Three samples were created from the ninhydrin treated prints. The DFO paper was observed using a 450nm light under an orange 
filter. Three samples were created from the DFO treated prints. Second, there is an additional sample to each time period totaling 6 for each period. Some latent palm prints were needed for six samples.

Three positive reagents (buccal swabs from both cheeks) and one negative control were created. The samples would go through the same process for extraction and quantitation.

New Amplification Set-Up

The Power Plex® 16 Amplification Kit from Promega Corporation was used for amplification. The calculation for the master mix is listed below in equation 4. Each sample contained $10 \mu \mathrm{L}$ master mix and $15 \mu \mathrm{L}$ of control, reagent, or sample. The same positive control standard (9947A) was used here along with a new positive control supplied with the Power Plex® kit: 2800M. The parameters for the thermocycler are listed below in Table 3.

Equation 4: Calculation of Amplification Master Mix for Power Plex ${ }^{\circledR} 16$

\# samples +9947 A positive control $+2800 M$ positive control +4 samples extra for error $=$ total samples

Water: total samples $x 4.2 \mu \mathrm{L}=$ total amount of water

Buffer: total samples $x 2.5 \mu \mathrm{L}=$ total amount of buffer

Primer Mix: total samples $2.5 \mu L=$ total amount of primer mix

AmpliTaq Gold DNA polymerase: total samples $x .8 \mu \mathrm{L}=$ total amount of DNA polymerase

Table 3: Parameters for the Power Plex ${ }^{\circledR} 16$ Run Setup on the ThermoCycler PCR System 9700

\begin{tabular}{|c|c|c|c|c|c|c|c|c|c|}
\hline \multicolumn{2}{|c|}{ Hot Start } & \multicolumn{3}{c|}{ Step One (10 cycles) } & \multicolumn{2}{c|}{ Step Two (22 cycles) } & $\begin{array}{c}\text { Final } \\
\text { Extension }\end{array}$ & Soak \\
\hline HOLD & HOLD & Denature & Anneal & Extend & Denature & Anneal & Extend & HOLD & HOLD \\
\hline $95^{\circ} \mathrm{C}$ & $96^{\circ} \mathrm{C}$ & $94^{\circ} \mathrm{C}$ & $60^{\circ} \mathrm{C}$ & $70^{\circ} \mathrm{C}$ & $90^{\circ} \mathrm{C}$ & $60^{\circ} \mathrm{C}$ & $70^{\circ} \mathrm{C}$ & $60^{\circ} \mathrm{C}$ & $4^{\circ} \mathrm{C}$ \\
\hline $\begin{array}{c}11.0 \\
\text { min }\end{array}$ & $\begin{array}{c}1.0 \\
\text { min }\end{array}$ & $30 \mathrm{sec}$ & $30 \mathrm{sec}$ & $45 \mathrm{sec}$ & $30 \mathrm{sec}$ & $30 \mathrm{sec}$ & $45 \mathrm{sec}$ & $30 \mathrm{~min}$ & (forever) \\
\hline
\end{tabular}


New Analysis Set-Up

A new analysis procedure was prepared in accordance with the Lake County Crime Laboratory Biology Procedure Manual [60]. The mixture amounts to create the solution for analysis were the same with the exception of adding $1.0 \mu \mathrm{L}$ to each tube. The sample tubes were placed in a 48-well tray and analyzed using an ABI Prism® 310 Genetic Analyzer. Results were observed and recorded.

\section{Results}

\section{Quantitation}

The results from Phase I quantitation are displayed below in Table 4. The Table shows the sample, the amount of DNA in $n g / \mu \mathrm{L}$, and the amount of DNA in $\mathrm{pg} / \mu \mathrm{L}$. For the first amplification and analysis, every sample was selected. The samples selected for the second set of amplification and analyses are highlighted. The selected samples for the second set were amplified in triplicate. 
Table 4: Quantitation Results from Phase I in $(n g / \mu L)$ and in $(p g / \mu L)$

\begin{tabular}{|c|c|c|c|c|c|c|c|c|}
\hline Sample & $\begin{array}{c}\text { Amount of } \\
\text { DNA }(n g / \mu L)\end{array}$ & $\mathrm{pg} / \mu \mathrm{L}$ & Sample & $\begin{array}{c}\text { Amount of } \\
\text { DNA }(n g / \mu L)\end{array}$ & $\mathrm{pg} / \mu \mathrm{L}$ & Sample & $\begin{array}{c}\text { Amount of } \\
\text { DNA }(n g / \mu L)\end{array}$ & $\mathrm{pg} / \mu \mathrm{L}$ \\
\hline $1-1$ & $1.51 \mathrm{E}-03$ & 1.51 & $1-21$ & $2.22 \mathrm{E}-02$ & 22.20 & $1-41$ & $2.12 \mathrm{E}-02$ & 21.20 \\
\hline $1-2$ & $1.00 \mathrm{E}-02$ & 10.00 & $1-22$ & $2.21 \mathrm{E}-02$ & 22.10 & $1-42$ & $1.92 \mathrm{E}-02$ & 19.20 \\
\hline $1-3$ & $6.68 \mathrm{E}-04$ & 0.67 & $1-23$ & $1.13 \mathrm{E}-01$ & 113.00 & $1-43$ & $1.41 \mathrm{E}-02$ & 14.10 \\
\hline $1-4$ & $1.40 \mathrm{E}-02$ & 14.00 & $1-24$ & $2.30 \mathrm{E}-02$ & 23.00 & $1-44$ & $1.77 \mathrm{E}-02$ & 17.70 \\
\hline $1-5$ & --- & 0.00 & $1-25$ & $2.37 \mathrm{E}-02$ & 23.70 & $1-45$ & $2.18 \mathrm{E}-02$ & 21.80 \\
\hline $1-6$ & $3.62 \mathrm{E}-02$ & 36.20 & $1-26$ & $2.22 \mathrm{E}-02$ & 22.20 & $1-46$ & $1.59 \mathrm{E}-02$ & 15.90 \\
\hline $1-7$ & $3.00 \mathrm{E}-02$ & 30.00 & $1-27$ & $2.26 \mathrm{E}-02$ & 22.60 & $1-47$ & $7.34 \mathrm{E}-03$ & 7.34 \\
\hline $1-8$ & --- & 0.00 & $1-28$ & $3.10 \mathrm{E}-02$ & 31.00 & $1-48$ & $1.48 \mathrm{E}-02$ & 14.80 \\
\hline $1-9$ & $3.26 \mathrm{E}-03$ & 3.26 & $1-29$ & $2.57 \mathrm{E}-02$ & 25.70 & $1-49$ & $8.86 \mathrm{E}-03$ & 8.86 \\
\hline $1-10$ & $6.68 \mathrm{E}-03$ & 6.68 & $1-30$ & $2.60 \mathrm{E}-02$ & 26.00 & $1-50$ & $2.20 \mathrm{E}-02$ & 22.00 \\
\hline $1-11$ & --- & 0.00 & $1-31$ & $3.48 \mathrm{E}-02$ & 34.80 & $1-51$ & $4.29 \mathrm{E}-02$ & 42.90 \\
\hline $1-12$ & --- & 0.00 & $1-32$ & $8.58 \mathrm{E}-03$ & 8.58 & $1-52$ & $1.55 \mathrm{E}-02$ & 15.50 \\
\hline $1-13$ & $3.20 \mathrm{E}-03$ & 3.20 & $1-33$ & $1.31 \mathrm{E}-02$ & 13.10 & $1-53$ & $2.15 \mathrm{E}-02$ & 21.50 \\
\hline $1-14$ & --- & 0.00 & $1-34$ & $2.59 \mathrm{E}-02$ & 25.90 & $1-54$ & $2.26 \mathrm{E}-02$ & 22.60 \\
\hline $1-15$ & --- & 0.00 & $1-35$ & $1.03 \mathrm{E}-02$ & 10.30 & $1-55$ & $2.28 \mathrm{E}-02$ & 22.80 \\
\hline $1-16$ & --- & 0.00 & $1-36$ & $2.41 \mathrm{E}-02$ & 24.10 & $1-56$ & $2.11 \mathrm{E}-02$ & 21.10 \\
\hline $1-17$ & $8.73 \mathrm{E}-03$ & 8.73 & $1-37$ & $2.17 \mathrm{E}-02$ & 21.70 & $1-57$ & $1.81 \mathrm{E}-02$ & 18.10 \\
\hline $1-18$ & --- & 0.00 & $1-38$ & $1.71 \mathrm{E}-02$ & 17.10 & $1-58$ & $2.18 \mathrm{E}-02$ & 21.80 \\
\hline $1-19$ & --- & 0.00 & $1-39$ & $2.37 \mathrm{E}-02$ & 23.70 & $1-59$ & $2.19 \mathrm{E}-02$ & 21.90 \\
\hline $1-20$ & --- & 0.00 & $1-40$ & $2.75 \mathrm{E}-02$ & 27.50 & $1-60$ & $2.88 \mathrm{E}-02$ & 28.80 \\
\hline \multicolumn{9}{|c|}{$\begin{array}{c}\mathrm{n}=60 \\
\text { Average amount }(\mathrm{pg} / \mu \mathrm{L}): 21.05 \\
\text { Standard Deviation: } 15.85\end{array}$} \\
\hline
\end{tabular}


The average amount of DNA and standard deviation from three sets of the same time process and the sequence process from Phase I quantitation is shown in Table 5 and Figure 2. The highest average amount of DNA from Phase I occurred during the second set of the same time process.

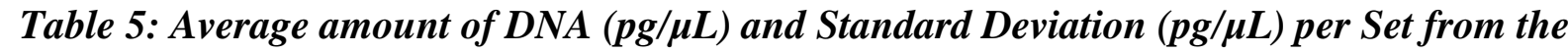
Same Time Process and the Sequence Process from Phase I Quantitation

\begin{tabular}{|c|c|c|}
\hline Set $(\mathbf{n}=\mathbf{1 0} / \mathbf{p r o c e s s})$ & Average $(\mathbf{p g} / \mathbf{\mu L})$ & Std. Dev. $(\mathbf{p g} / \boldsymbol{\mu L})$ \\
\hline Same Time 1 & 10.23 & 12.32 \\
\hline Sequence 1 & 1.19 & 2.69 \\
\hline Same Time 2 & 33.15 & 26.74 \\
\hline Sequence 2 & 20.68 & 7.87 \\
\hline Same Time 3 & 16.29 & 4.9 \\
\hline Sequence 3 & 23.7 & 7.17 \\
\hline
\end{tabular}

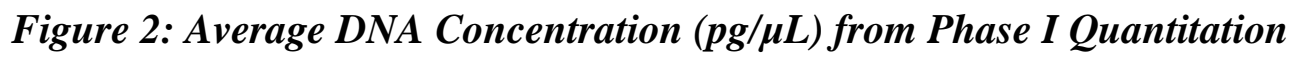

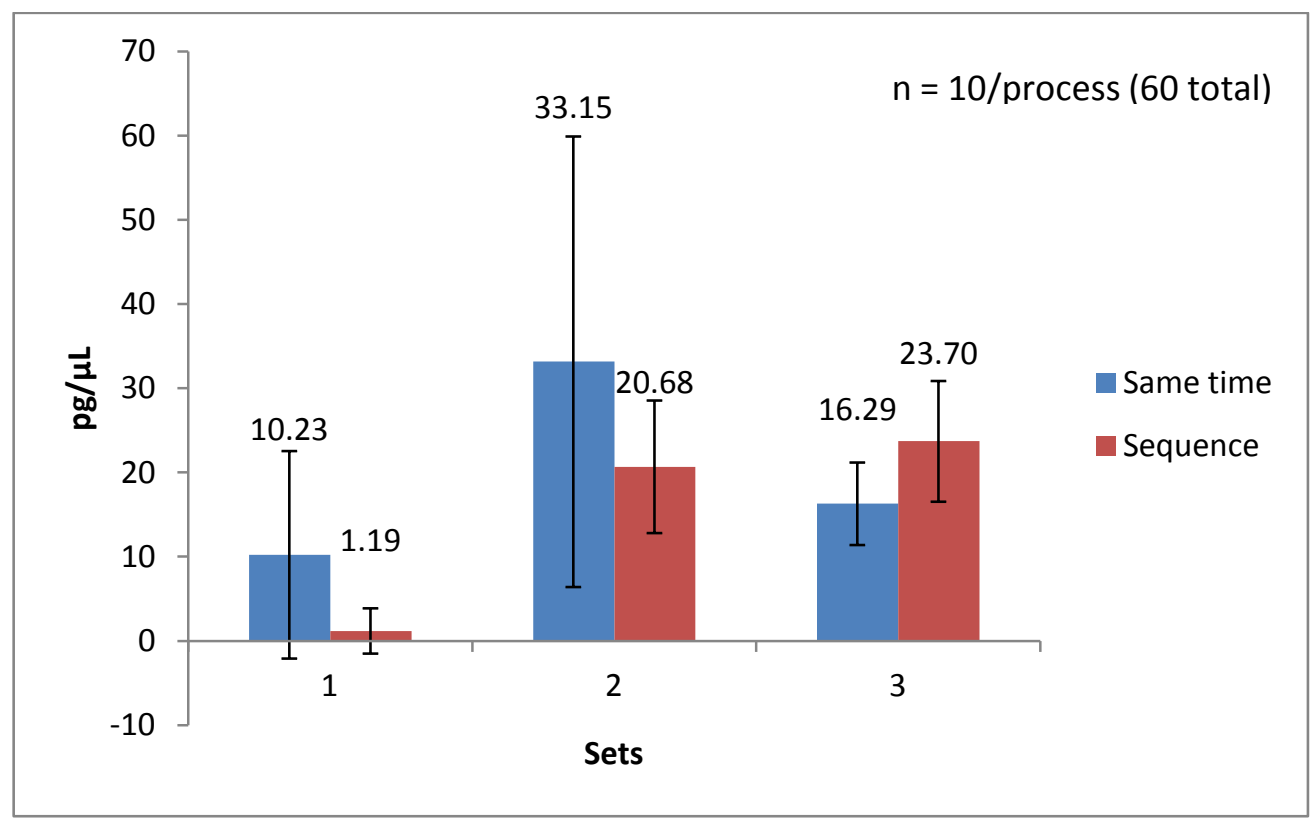


The quantitation results from Phase II are described in below in Table 6. The table shows the sample, the amount of DNA in $n g / \mu \mathrm{L}$, and the amount of DNA in $\mathrm{pg} / \mu \mathrm{L}$. The amount of DNA in Phase II is less than the amount from Phase I. The sample selected for the second set of amplification and analysis is highlighted. The selected sample was amplified in triplicate.

Table 7 and Figure 3 show the average amount of DNA and standard deviation from quantitation per hour period from Phase II. Generally, the average amount of DNA increased from 3 hours $(6.05 \mathrm{pg} / \mu \mathrm{L})$ to 48 hours $(13.53 \mathrm{pg} / \mu \mathrm{L})$. However, the average amount of DNA from Phase II is still lower than the average amount of DNA from Phase I. 
Table 6: Quantitation Results from Phase II in $(n g / \mu L)$ and in $(\mathrm{pg} / \mu L)$

\begin{tabular}{|c|c|c|c|c|c|c|c|c|}
\hline Sample & $\begin{array}{l}\text { Amount of } \\
\text { DNA } \\
(\mathrm{ng} / \mu \mathrm{L})\end{array}$ & $\mathrm{pg} / \mu \mathrm{L}$ & Sample & $\begin{array}{l}\text { Amount of } \\
\text { DNA } \\
(\mathrm{ng} / \mu \mathrm{L})\end{array}$ & $\mathrm{pg} / \mu \mathrm{L}$ & Sample & $\begin{array}{l}\text { Amount of } \\
\text { DNA } \\
(\mathrm{ng} / \mu \mathrm{L})\end{array}$ & $\mathrm{pg} / \mu \mathrm{L}$ \\
\hline $1-1$ & $7.39 \mathrm{E}-03$ & 7.39 & $12-1$ & $7.12 \mathrm{E}-03$ & 7.12 & $72-1$ & $6.96 \mathrm{E}-03$ & 6.96 \\
\hline $1-2$ & $4.46 \mathrm{E}-03$ & 4.46 & $12-2$ & $4.61 \mathrm{E}-03$ & 4.61 & $72-2$ & $6.22 \mathrm{E}-03$ & 6.22 \\
\hline $1-3$ & $4.30 \mathrm{E}-03$ & 4.30 & $12-3$ & $1.41 \mathrm{E}-02$ & 14.10 & $72-3$ & $1.83 \mathrm{E}-03$ & 1.83 \\
\hline $1-4$ & $1.08 \mathrm{E}-02$ & 10.80 & $12-4$ & $6.27 \mathrm{E}-03$ & 6.27 & $72-4$ & $8.82 \mathrm{E}-03$ & 8.82 \\
\hline $1-5$ & $1.28 \mathrm{E}-02$ & 12.80 & $12-5$ & $1.21 \mathrm{E}-02$ & 12.10 & $72-5$ & $1.38 \mathrm{E}-02$ & 13.80 \\
\hline $2-1$ & $3.22 \mathrm{E}-02$ & 32.20 & $24-1$ & $1.31 \mathrm{E}-02$ & 13.10 & 96-1 & $1.56 \mathrm{E}-02$ & 15.60 \\
\hline $2-2$ & $1.06 \mathrm{E}-02$ & 10.60 & $24-2$ & $1.61 \mathrm{E}-02$ & 16.10 & 96-2 & $7.03 \mathrm{E}-03$ & 7.03 \\
\hline $2-3$ & $1.86 \mathrm{E}-02$ & 18.60 & $24-3$ & 9.94E-03 & 9.94 & 96-3 & $8.71 \mathrm{E}-03$ & 8.71 \\
\hline $2-4$ & $1.01 \mathrm{E}-02$ & 10.10 & $24-4$ & $1.18 \mathrm{E}-02$ & 11.80 & $96-4$ & $2.07 \mathrm{E}-03$ & 2.07 \\
\hline $2-5$ & $7.89 \mathrm{E}-03$ & 7.89 & $24-5$ & $9.79 \mathrm{E}-03$ & 9.79 & $96-5$ & $1.81 \mathrm{E}-03$ & 1.81 \\
\hline 3-1 & $1.07 \mathrm{E}-02$ & 10.70 & 36-1 & $1.10 \mathrm{E}-02$ & 11.00 & $120-1$ & $1.20 \mathrm{E}-02$ & 12.00 \\
\hline $3-2$ & $7.12 \mathrm{E}-03$ & 7.12 & $36-2$ & $1.53 \mathrm{E}-02$ & 15.30 & $120-2$ & $1.66 \mathrm{E}-02$ & 16.60 \\
\hline $3-3$ & $2.62 \mathrm{E}-03$ & 2.62 & $36-3$ & $5.27 \mathrm{E}-03$ & 5.27 & $120-3$ & $1.18 \mathrm{E}-02$ & 11.80 \\
\hline $3-4$ & $4.55 \mathrm{E}-03$ & 4.55 & $36-4$ & $9.48 \mathrm{E}-03$ & 9.48 & $120-4$ & $1.12 \mathrm{E}-02$ & 11.20 \\
\hline $3-5$ & $5.24 \mathrm{E}-03$ & 5.24 & $36-5$ & $1.74 \mathrm{E}-02$ & 17.40 & $120-5$ & $7.37 \mathrm{E}-03$ & 7.37 \\
\hline $6-1$ & $4.69 \mathrm{E}-03$ & 4.69 & $48-1$ & $2.18 \mathrm{E}-02$ & 21.80 & & & \\
\hline $6-2$ & $4.19 \mathrm{E}-03$ & 4.19 & $48-2$ & $6.77 \mathrm{E}-03$ & 6.77 & & & \\
\hline $6-3$ & $5.17 \mathrm{E}-03$ & 5.17 & $48-3$ & $9.60 \mathrm{E}-03$ & 9.60 & & & \\
\hline $6-4$ & $1.18 \mathrm{E}-02$ & 11.80 & 48-4 & $9.30 \mathrm{E}-03$ & 9.30 & & & \\
\hline $6-5$ & $1.07 \mathrm{E}-02$ & 10.70 & $48-5$ & $2.02 \mathrm{E}-02$ & 20.20 & & & \\
\hline \multicolumn{9}{|c|}{$\begin{array}{l}\mathrm{n}=55 \\
\text { Average Amount }(\mathrm{pg} / \mu \mathrm{L}): 9.98 \\
\text { Standard Deviation: } 5.52\end{array}$} \\
\hline
\end{tabular}




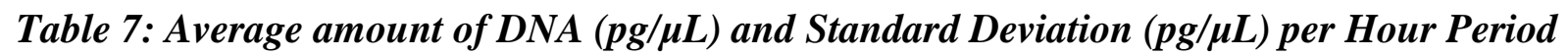
from Phase II Quantitation

\begin{tabular}{|c|c|c|}
\hline Hour $(\mathbf{n}=\mathbf{5} / \mathbf{h r})$ & Average $(\mathbf{p g} / \boldsymbol{\mu L})$ & Std. Dev. $(\mathbf{p g} / \boldsymbol{\mu L})$ \\
\hline $\mathbf{1}$ & 7.95 & 3.39 \\
\hline $\mathbf{2}$ & 15.88 & 8.93 \\
\hline $\mathbf{3}$ & 6.05 & 2.74 \\
\hline $\mathbf{6}$ & 7.31 & 3.25 \\
\hline $\mathbf{1 2}$ & 8.84 & 3.63 \\
\hline $\mathbf{2 4}$ & 12.15 & 2.33 \\
\hline $\mathbf{3 6}$ & 11.69 & 4.29 \\
\hline $\mathbf{4 8}$ & 13.53 & 6.20 \\
\hline $\mathbf{7 2}$ & 7.53 & 3.89 \\
\hline $\mathbf{9 6}$ & 7.04 & 5.06 \\
\hline $\mathbf{1 2 0}$ & 11.79 & 2.93 \\
\hline
\end{tabular}

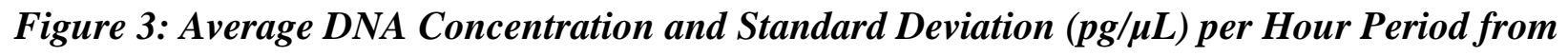
Phase II Quantitation

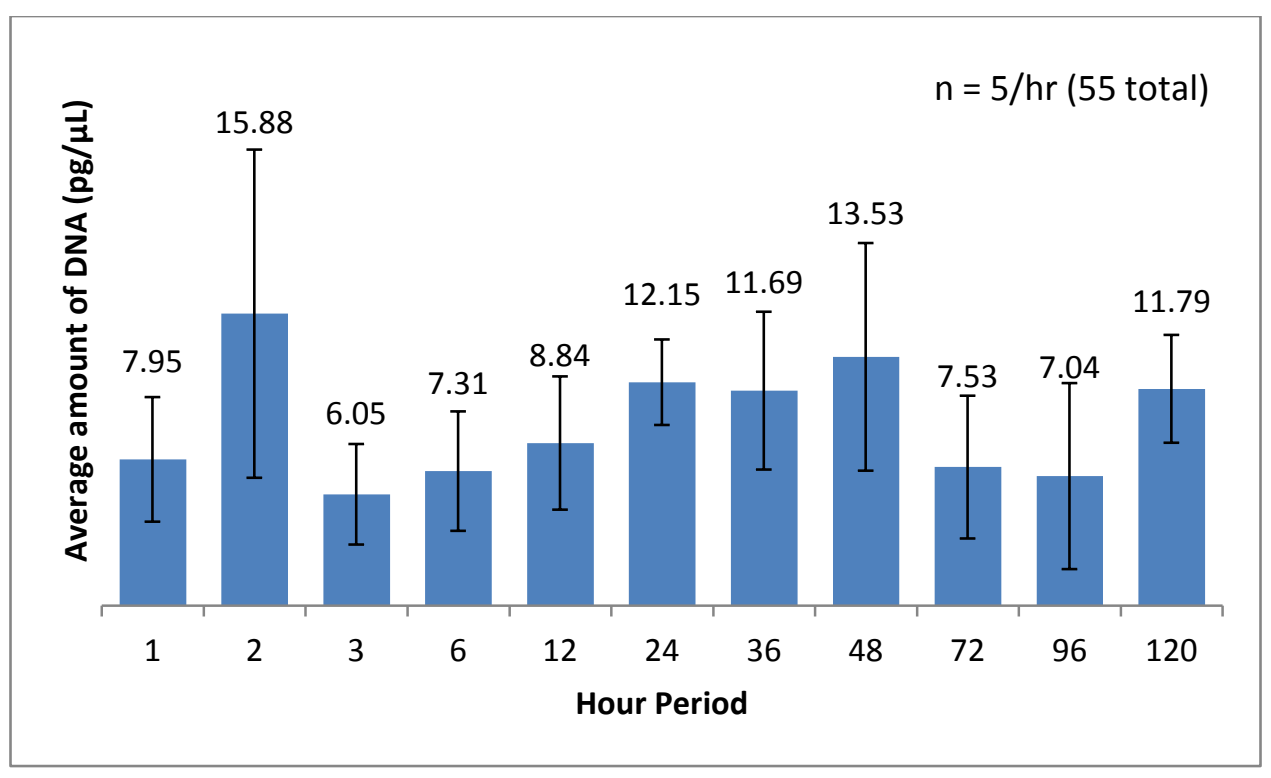


The quantitation results from Phase III are described in below in Table 8. The table shows the sample, the amount of DNA in $\mathrm{ng} / \mu \mathrm{L}$, and the amount of DNA in $\mathrm{pg} / \mu \mathrm{L}$. The amount of DNA in Phase III is the lowest amount quantitated out of the three phases. The largest amount quantitated from Phase III was 96-1 which was 4.39pg. The samples selected for the third set of amplification and analyses are highlighted. These samples were not analyzed in triplicate.

Table 9 and Figure 4 compare the average amount of DNA and standard deviation quantitated from the applications of either ninhydrin or DFO. The amounts varied from no amount detected (ninhydrin-hour two) to $1.93 \mathrm{pg} / \mu \mathrm{L}$ (ninhydrin-96 hour). There is no general trend found in the results from Phase III quantitation. It should be stated that no other statistical analysis was performed with the data. 
Table 8: Quantitation Results from Phase III in $(n g / \mu L)$ and in $(p g / \mu L)$

\begin{tabular}{|c|c|c|c|c|c|c|c|c|}
\hline Sample & $\begin{array}{c}\text { Amount of } \\
\text { DNA }(n g / \mu L)\end{array}$ & $\mathrm{pg} / \mu \mathrm{L}$ & Sample & $\begin{array}{c}\text { Amount of DNA } \\
(\mathrm{ng} / \mu \mathrm{L})\end{array}$ & $\mathrm{pg} / \mu \mathrm{L}$ & Sample & $\begin{array}{c}\text { Amount of } \\
\text { DNA }(n g / \mu L)\end{array}$ & $\mathrm{pg} / \mu \mathrm{L}$ \\
\hline $1-1$ & --- & 0.00 & 12-1 & --- & 0.00 & $72-1$ & $4.45 \mathrm{E}-04$ & 0.45 \\
\hline $1-2$ & $5.49 \mathrm{E}-04$ & 0.55 & $12-2$ & $2.61 \mathrm{E}-04$ & 0.26 & $72-2$ & $6.87 \mathrm{E}-04$ & 0.69 \\
\hline $1-3$ & --- & 0.00 & $12-3$ & $5.46 \mathrm{E}-04$ & 0.55 & $72-3$ & $3.37 \mathrm{E}-04$ & 0.34 \\
\hline $1-4$ & $7.22 \mathrm{E}-04$ & 0.72 & $12-4$ & --- & 0.00 & $72-4$ & 7.02E-04 & 0.70 \\
\hline $1-5$ & --- & 0.00 & $12-5$ & --- & 0.00 & $72-5$ & --- & 0.00 \\
\hline $1-6$ & $2.19 \mathrm{E}-03$ & 2.19 & $12-6$ & $9.58 \mathrm{E}-04$ & 0.96 & $72-6$ & $1.11 \mathrm{E}-03$ & 1.11 \\
\hline $2-1$ & --- & 0.00 & 24-1 & --- & 0.00 & 96-1 & $4.39 \mathrm{E}-03$ & 4.39 \\
\hline $2-2$ & --- & 0.00 & 24-2 & $1.43 \mathrm{E}-03$ & 1.43 & $96-2$ & $1.40 \mathrm{E}-03$ & 1.40 \\
\hline $2-3$ & --- & 0.00 & $24-3$ & $1.82 \mathrm{E}-03$ & 1.82 & $96-3$ & --- & 0.00 \\
\hline $2-4$ & $3.21 \mathrm{E}-04$ & 0.32 & $24-4$ & 4.61E-04 & 0.46 & 96-4 & --- & 0.00 \\
\hline $2-5$ & --- & 0.00 & $24-5$ & $4.48 \mathrm{E}-04$ & 0.45 & $96-5$ & --- & 0.00 \\
\hline $2-6$ & --- & 0.00 & $24-6$ & $6.51 \mathrm{E}-04$ & 0.65 & $96-6$ & $3.01 \mathrm{E}-04$ & 0.30 \\
\hline 3-1 & --- & 0.00 & $36-1$ & --- & 0.00 & $120-1$ & $6.89 \mathrm{E}-04$ & 0.69 \\
\hline $3-2$ & --- & 0.00 & $36-2$ & $8.83 \mathrm{E}-04$ & 0.88 & $120-2$ & --- & 0.00 \\
\hline $3-3$ & $3.31 \mathrm{E}-04$ & 0.33 & $36-3$ & $2.39 \mathrm{E}-03$ & 2.39 & $120-3$ & $8.18 \mathrm{E}-04$ & 0.82 \\
\hline $3-4$ & $3.29 \mathrm{E}-04$ & 0.33 & $36-4$ & --- & 0.00 & 120-4 & $3.95 \mathrm{E}-04$ & 0.40 \\
\hline $3-5$ & --- & 0.00 & $36-5$ & $4.33 \mathrm{E}-04$ & 0.43 & $120-5$ & $2.38 \mathrm{E}-03$ & 2.38 \\
\hline $3-6$ & $6.91 \mathrm{E}-04$ & 0.69 & 36-6 & $6.91 \mathrm{E}-04$ & 0.69 & $120-6$ & $3.06 \mathrm{E}-04$ & 0.31 \\
\hline $6-1$ & 7.17E-04 & 0.72 & 48-1 & $9.53 \mathrm{E}-04$ & 0.95 & \multirow{2}{*}{\multicolumn{3}{|c|}{$\begin{array}{l}\mathrm{n}=66 \\
\text { Average Amount }(\mathrm{pg} / \mu \mathrm{L}): .56 \\
\text { Standard Deviation: } .77\end{array}$}} \\
\hline $6-2$ & --- & 0.00 & 48-2 & $2.64 \mathrm{E}-04$ & 0.26 & & & \\
\hline $6-3$ & --- & 0.00 & $48-3$ & $1.61 \mathrm{E}-03$ & 1.61 & & & \\
\hline $6-4$ & $1.72 \mathrm{E}-03$ & 1.72 & $48-4$ & $3.71 \mathrm{E}-04$ & 0.37 & & & \\
\hline $6-5$ & $4.41 \mathrm{E}-04$ & 0.44 & $48-5$ & $4.88 \mathrm{E}-04$ & 0.49 & & & \\
\hline $6-6$ & --- & 0.00 & $48-6$ & 2.32E-04 & 0.23 & & & \\
\hline
\end{tabular}


Table 9: Average Amount of DNA $(\mathrm{pg} / \mu \mathrm{L})$ and Standard Deviation $(\mathrm{pg} / \mu \mathrm{L})$ from the Application of Ninhydrin or DFO from Phase III

\begin{tabular}{|c|c|c|c|c|}
\hline $\begin{array}{c}\text { Hour } \\
(\mathbf{n}=\mathbf{6} / \mathbf{h r})\end{array}$ & $\begin{array}{c}\text { Average } \\
\text { Ninhydrin } \\
(\mathbf{p g} / \mathbf{\mu L}) \\
(\mathbf{n}=\mathbf{3} / \mathbf{h r})\end{array}$ & $\begin{array}{c}\text { Std Dev. } \\
(\mathbf{p g} / \boldsymbol{\mu L})\end{array}$ & $\begin{array}{c}\text { Average } \\
\mathbf{D F O}(\mathbf{p g} / \mathbf{\mu L} \mathbf{L}) \\
(\mathbf{n}=\mathbf{3} / \mathbf{h r})\end{array}$ & $\begin{array}{c}\text { Std. Dev. } \\
(\mathbf{p g} / \boldsymbol{\mu L})\end{array}$ \\
\hline $\mathbf{1}$ & 0.18 & 0.26 & 0.97 & 0.91 \\
\hline $\mathbf{2}$ & 0 & 0 & 0.11 & 0.15 \\
\hline $\mathbf{3}$ & 0.11 & 0.16 & 0.34 & 0.28 \\
\hline $\mathbf{6}$ & 0.24 & 0.34 & 0.72 & 0.73 \\
\hline $\mathbf{1 2}$ & 0.27 & 0.22 & 0.32 & 0.45 \\
\hline $\mathbf{2 4}$ & 1.08 & 0.78 & 0.52 & 0.09 \\
\hline $\mathbf{3 6}$ & 1.09 & 0.99 & 0.37 & 0.29 \\
\hline $\mathbf{4 8}$ & 0.94 & 0.55 & 0.36 & 0.1 \\
\hline $\mathbf{7 2}$ & 0.49 & 0.15 & 0.6 & 0.46 \\
\hline $\mathbf{9 6}$ & 1.93 & 1.83 & 0.1 & 0.14 \\
\hline $\mathbf{1 2 0}$ & 0.5 & 0.34 & 1.03 & 0.96 \\
\hline
\end{tabular}

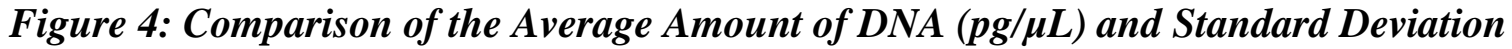
$(\mathrm{pg} / \mu \mathrm{L})$ from the Application of Ninhydrin or DFO from Phase III

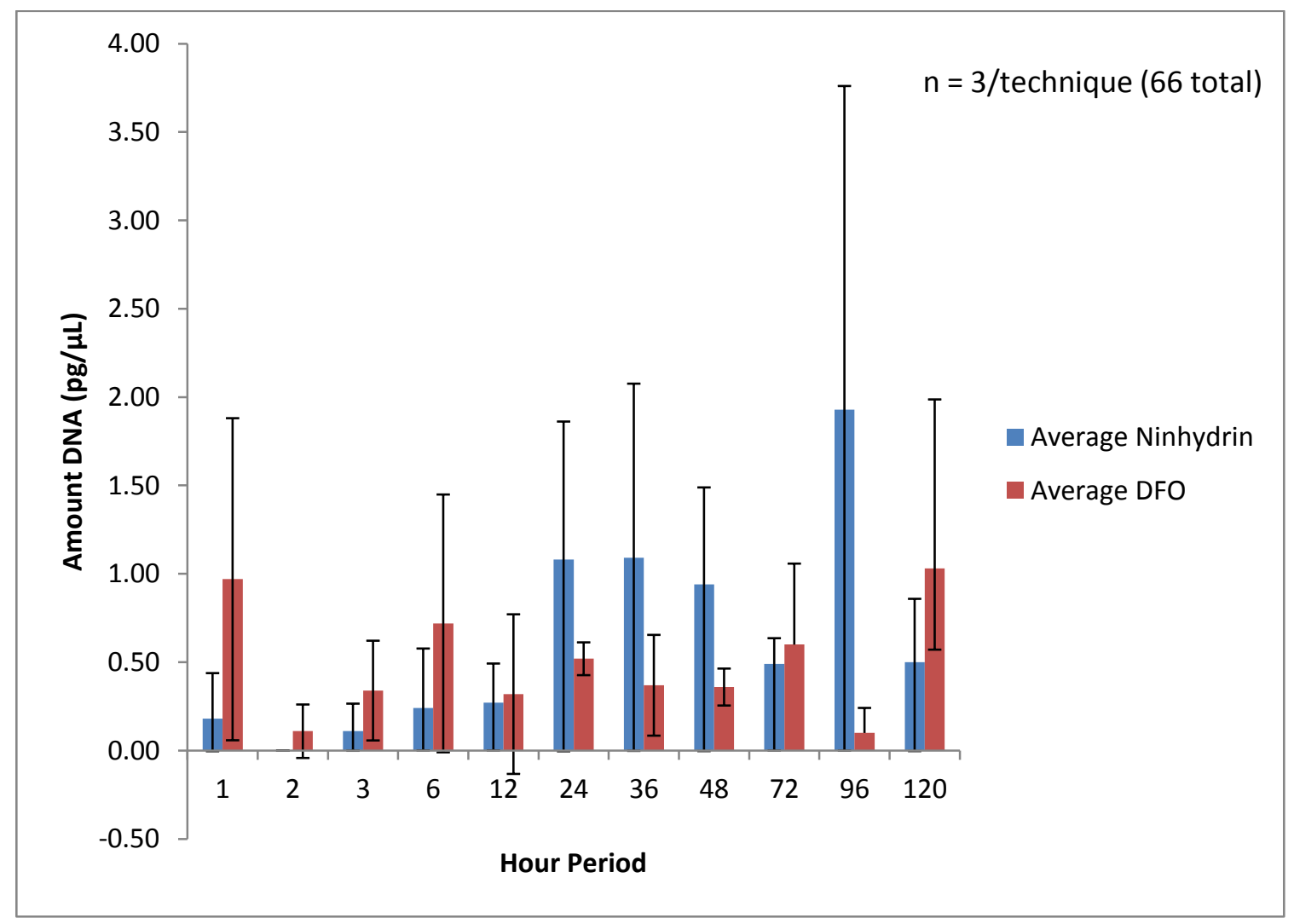




\section{Analysis}

Full profiles from the allelic ladder and the positive control (9947A) were created in the first analysis set. A partial profile from one of the positive reagents (PR2) was created from the first set of analysis set. A full profile from the allelic ladder and partial profiles from the two positive controls (9947A and $2800 \mathrm{M}$ ) were created from the third analysis set. There was no recovery of DNA profiles from any samples analyzed, which included most of the positive reagents (buccal swabs from the cheeks) and all samples from the first and third analysis set. No statistical analysis was performed because there were negative results.

Amplification set \#2 was amplified, but not analyzed. Amplification set \#2 was amplified with AMPFlSTR® Identifiler® unknowingly after the United States District Court for the Western District of Wisconsin ruled that AMPFlSTR® Identifiler® is used for forensic and paternity testing only [61]. The set was held in storage after hearing about the ruling.

\section{Discussion}

The results from the tables show very low amounts of DNA were found from quantitation for all three phases using these procedures. Results were found to be in low $\mathrm{pg} / \mu \mathrm{L}$ and not in the desirable $\mathrm{ng} / \mu \mathrm{L}$ range. This is to be expected from fingerprints on paper as previous authors have stated [52, 56-59]. The authors also demonstrated their results by using percentage of the profile recovered. Percentage of profile recovery would have been done if results were more favorable.

It is very difficult to find DNA amounts from fingerprints in the $n g / \mu \mathrm{L}$ range. The paper had debris in the form of dust or dirt before a fingerprint was deposited. The person could have 
washed their hands or rubbed their hands together before touching the surface. The person could have touched the surface for a very short amount of time. These possibilities are all reasons why such low levels of DNA amounts occurred in the results. However, according to past research levels of DNA amounts around $30 \mathrm{pg} / \mu \mathrm{L}$ were still able to create and recover full profiles, but started recovering stochastic results when the source level was at $10 \mathrm{pg} / \mu \mathrm{L}[48,50]$. Amplifying DNA less than $10 \mathrm{pg} / \mu \mathrm{L}$ in a sample is not recommended because amplifying extreme low amounts can lead to negative results or allelic drop-ins. Amplifying low amounts of DNA is very risky if it is used in casework protocol.

The results from Phase III had the lowest amounts of DNA out of all three phases. Phase III research included papers that sat in a typical house setting and dipping into a ninhydrin solution or spraying with DFO. Dipping or spraying the paper with these reagents dislodged some of the epithelial cells from the paper. The results from Phase III confirm what Sewell found when ninhydrin or DFO was applied to paper [58]. The application of ninhydrin or DFO does result in a reduction of recovered DNA profiles. In Sewell's case, it caused a " $60 \%$ fold reduction", but profiles were still recovered [58]. In this case, no profiles were recovered.

Phase II research showed some favorable results. The amount of DNA quantitated from the samples generally increased from the 3 hour period to the 48 hour period. DNA recovery occurred because the epithelial cells on the paper found microscopic holes in the paper. With more time elapsing, the paper absorbed the fingerprint more and an increased amount of cells could be found there. This occurrence correlates to what Wickenheiser found during the study of touch DNA [22]. Wickenheiser determined that more DNA could be recovered from porous surfaces than nonporous surfaces because the cells could find small areas to hide in. On the other hand, there should be a general increase from the 3 hour period to the 120 hour period then. 
This general assumption did not occur. Phase I and Phase III showed random average amounts of DNA for each set or hour period. This could be an effect from pre-placement activity, such as rubbing hands together or rubbing hands on the neck or hair. Some of epithelial cells could have dislodged from the hand or not enough activity occurred for a sufficient amount of DNA to be quantitated.

As stated in the results, no sample DNA profiles were recovered after amplification and analysis of Phase I and Phase III. The allelic ladder in the first and third sets of analysis (all of Phase I) was recovered properly. The positive control (9947A) in the first set recorded a full profile while both positive controls (9947A and $2800 \mathrm{M})$ in the third set recorded partial profiles. The second positive reagent in the first set of analysis showed a partial profile, but the peaks were small and weak. A potential problem in the first set of amplification and analysis was the parameters of the thermocycler. The thermocycler was set for the normal 28 cycles of amplification. Previous literature and presentations show that any amplification for LTDNA needs to be at least 31 cycles $[25,33,34]$. Degradation could have been a factor in Phase III analysis because the samples were taken out of a freezer and placed in a Styrofoam container with frozen ice packs. The container could have been slightly warmer than the freezer, but not a significant factor. There could be not enough amount of DNA to amplify in the first and third set of analysis. Since there was very low amounts of DNA found in all three phases, the Taq Polymerase probably could not have found the primers and the binding site.

Another factor could be contamination that occurred through extraction. Even though extraction of DNA from paper occurred in a sterile hood, the extraction method itself could have caused contamination. The constant changing of tubes and numerous pipetting could have lost numerous DNA strands that could not be recovered. In the phenol-chloroform extraction, there 
were three tube changes in the washing of the sample with chloroform alone. Also, there was the pipetting to a concentrator and constant washing. The DNA strands should have adhered to the concentrator and stayed on during the three washings with distilled water.

The second set of analysis could have given the most optimal results. Selected samples above $25 \mathrm{pg} / \mu \mathrm{L}$ from Phase I and Phase II were amplified in triplicate, according to authors [21, $24,25,33]$. The intention of one sample producing three amplified products was to create replication. With LTDNA, replication has the potential to create a combined full profile using all three samples. Even if the samples from Phase I and Phase II did not have the application of ninhydrin or DFO, it would have significantly resulted in profiles that could be recovered from fingerprints. Unfortunately, the samples were amplified with AMPFlSTR® Identifiler® after the ruling of the United States District Court for the Western District of Wisconsin [61]. Research with AMPFlSTR® Identifiler@ amplification had to cease once it was known about this ruling.

It is difficult to recover DNA profiles from fingerprints. Research has shown that even though the epithelial cells from a fingerprint is enough for a full profile, there had to be a modification in the DNA analysis procedure that optimized LTDNA, such as increased cycles or increased amounts of reagents used [23, 52, 56-59]. One of the most important things needed for a DNA laboratory is the status of sterilization. A DNA lab needs to be void of contamination. Otherwise, results will be faulty and lose their credibility. When analyzing for LTDNA, the lab and the examiner must make sterilization a top priority because of the small amount of DNA that is potentially present.

This research was attempted to recover profiles under a typical house setting; dust and dirt can collect on things before being analyzed. Dust and dirt present contamination and degraded 
DNA to the analysis, especially for LTDNA. Previous authors have stated that ninhydrin and DFO can reduce the recovery of profiles, but not completely inhibit them $[52-54,58]$. It was seen that ninhydrin and DFO, coupled with paper found in house settings, will inhibit recovery of profiles and lead to negative results.

LTDNA from fingerprints is a very risky source of DNA. The application of ninhydrin and DFO reduces the probability of recovering any DNA profiles. It would be highly recommended that the forensic scientist or examiner exhaust all other options of analysis before attempting to recover profiles from fingerprints on paper after the application of ninhydrin or DFO. This includes if the paper has been sitting for a significant time or not. 


\section{Future Research}

Even though the current research did not develop the results as expected, it did generate suggestions and recommendations for future research. Since the phenol chloroform extraction method yielded low amounts of DNA, it is suggested to switch the extraction method to a method that does not use numerous microcentrifuge tube changes. One possible method is the Chelex® 100 Extraction Method. This method does not require as numerous microcentrifuge tube changes and is less of a health hazard than the phenol chloroform extraction method. Another suggestion is to handle the paper mimicking the turning of a page. This introduces more contact between the finger and the paper. This allows cells a more likely chance of adhering to the paper.

It is recommended to have a more sterile laboratory. Since fingerprints contain no to little amount of DNA, any contamination introduced to the process will inhibit results. The last recommendation is to utilize an amplification kit that optimizes low template DNA. The commercial kits used for this research were not sensitive enough to amplify DNA in the samples leading to negative results. A more sensitive kit that is aimed to amplify low amounts of DNA can help create profiles.

\section{Acknowledgements}

I would like to personally thank Dr. Keith Morris and Tina Moroose through the twists and turns of my research process. This includes their time, the supplies, and the surprising court ruling. I would also like to thank the Lake County Crime Laboratory, especially the lab director, Linda Erdei, and the DNA Technical Leader, Dr. Steve LaBonne, for allowing me permission to analyze my final set of amplification. 


\section{References}

1. $\quad$ DNA Interactive. "The First DNA Fingerprint, Alec Jeffreys :: DNA Learning Center." The First DNA Fingerprint, Alec Jeffreys :: DNA Learning Center. Cold Spring Harbor Laboratory, n.d. Web. 19 July 2012. <http://www.dnalc.org/view/15103-The-first-DNA-fingerprint-Alec-Jeffreys.html>.

2. Butler, J.M., Forensic DNA Typing: Biology, Technology, and Genetics of STR Markers. 2nd ed. 2005, Burlington, MA: Elsevier. 660.

3. Watson, J.D. and F.H.C. Crick, Molecular Structure of Nucleic Acids: A Structure for Deoxyribose Nucleic Acid. Nature, 1953. 171(4356): p. 2.

4. Kaye, D.H. and G. Sensabaugh, Reference Guide on DNA Identification Evidence, in Reference Manual on Scientific Evidence. 2011, National Academy of Sciences, Federal Judicial Center: Washington, D.C. p. 1034.

5. $\quad$ Gill, P., Jeffreys A., Werret, D., Forensic Applications of DNA 'fingerprints'. Nature, 1985. 318: 577-9.

6. Shipp, E., et al., Effects of Argon Laser Light, Alternate Source Light, and Cyanoacrylate Fuming on DNA Typing of Human Bloodstains. Journal of Forensic Science, 1993. 38(1): p. 8.

7. Shaler, R., Modern Forensic Biology, in Forensic Science Handbook, R. Saferstein, Editor. 2002, Pearson Education: Upper Saddle River. p. 89.

8. Presley, L., A. Baumstark, and A. Dixon, The Effects of Specific Latent Fingerprint and Questioned Document Examinations on the Amplification and Typing of the HLA DQ alpha Gene Region in Forensic Casework. Journal of Forensic Sciences, 1993. 38(5): p. 9.

9. Saiki, R., D. Gelfand, S. Stoffel, S. Scharf, R. Higuchi, G. Horn, K. Mullis, and H. Erlich. "Primerdirected Enzymatic Amplification of DNA with a Thermostable DNA Polymerase." Science 239.4839 (1988): 487-91. Print.

10. Goodwin, W., A. Linacre, and S. Hadi, An Introduction to Forensic Genetics. 2007, West Sussex: John Wiley \& Sons Ltd. 151.

11. Glaister, J. "The Kastle-Meyer Test for the Detection of Blood: Considered from the MedicoLegal Aspect." British Medical Journal 1.3406 (1926): 650-52. Print.

12. Kaye, S. "Acid Phosphatase Test for Identification of Seminal Stains." The Journal of Laboratory and Clinical Medicine 34.5 (1949): 728-32. Print.

13. Chomzynski, P., and N. Sacchi. "Single-Step Method of RNA Isolation by Acid Guanidinium Thiocyanate-Phenol-Chloroform Extraction." Analytical Biochemistry 162.1 (1987): 156-59. Print.

14. Walsh, P. S., D. A. Metzger, and R. Higuchi. "Chelex 100 as a Medium for Simple Extraction of DNA for PCR-based Typing from Forensic Material." Biotechniques 10.4 (1991): 506-13. Print.

15. Stein, C., S. Kyeck, and C. Henssge, DNA Typing of Fingerprint Reagent Treated Biological Stains. Journal of Forensic Science, 1996. 41(6): p. 1012-1017.

16. Technologies, L. TaqMan(R) and SYBR(R) Green Chemistries. 2011 [cited 2012 March 30]; Description of TaqMan and SYBR Green based detection in Real-Time PCR]. Available from: http://www.appliedbiosystems.com/absite/us/en/home/applications-technologies/real-timepcr/tagman-and-sybr-green-chemistries.html.

17. Butler, J. M., and B. R. McCord. "Capillary Electrophoresis in DNA Analysis: Introduction to CE and ABI 310." NEAFS CE-DNA Workshop. NEAFS Workshop, Mystic, CT. 29-30 Sept. 2004. Lecture. 
18. NFSTC. "AmpFISTR (Applied Biosystems)." AmpFl,,"STR (Applied Biosystems). NFSTC, n.d. Web. 22 July 2012. <http://www.nfstc.org/pdi/Subject04/pdi_s04_m03_02_a.htm>.

19. NFSTC. "PowerPlex (Promega GenePrint ${ }^{\circledR}$ )." PowerPlex (Promega GenePrint ${ }^{\circledR}$ ). NFSTC, n.d. Web. 22 July 2012. <http://www.nfstc.org/pdi/Subject04/pdi_s04_m03_02_b.htm>.

20. $\quad$ DOJ FBI. "CODIS Brochure." FBI. FBI Laboratory Service, July 2010. Web. 22 July 2012. $<$ http://www.fbi.gov/about-us/lab/codis/codis_brochure>.

21. Gill, P., et al., An investigation of the rigor of interpretation rules for STRs derived from less than 100 pg of DNA. Forensic Science International, 2000. 112(1): p. 17-40.

22. Wickenheiser, R.A., Trace DNA: A review, discussion of theory, and application of the transfer of trace quantities of DNA through skin contact. Journal of Forensic Sciences, 2002. 47(3): p. 442450.

23. Kloosterman, A.D. and P. Kersbergen, Efficacy and limits of genotyping low copy number DNA samples by multiplex PCR of STR loci, in Progress in Forensic Genetics 9, B. Brinkman and A. Carracedo, Editors. 2003, Elsevier Science Bv: Amsterdam. p. 795-798.

24. Gill, P., Application of low copy number DNA profiling. Croatian Medical Journal, 2001. 42(3): p. 229-232.

25. Butler, John M., and Carolyn R. Hill. "Scientific Issues with Analysis of Low Amounts of DNA." 20th International Symposium on Human Identification. Las Vegas, NV. 15 Oct. 2009. Lecture.

26. van Oorschot, R.A.H., et al., Are you collecting all the available DNA from touched objects?, in Progress in Forensic Genetics 9, B. Brinkman and A. Carracedo, Editors. 2003, Elsevier Science Bv: Amsterdam. p. 803-807.

27. Weiler, N.E.C., A.S. Matai, and T. Sijen, Extended PCR conditions to reduce drop-out frequencies in low template STR typing including unequal mixtures. Forensic Science International-Genetics, 2012. 6(1): p. 102-107.

28. Cowen, S., et al., An investigation of the robustness of the consensus method of interpreting lowtemplate DNA profiles. Forensic Science International-Genetics, 2011. 5(5): p. 400-406.

29. Puch-Solis, R., et al., Practical determination of the low template DNA threshold. Forensic Science International-Genetics, 2011. 5(5): p. 422-427.

30. van Oorschot, R.A. and M.K. Jones, DNA Fingerprints from Fingerprints. Nature, 1997. 387(6635): p. 1.

31. Findlay, I., et al., DNA fingerprinting from single cells. Nature, 1997. 389: p. 555-556.

32. Renterghem, P.V., D. Leornard, and C. De Greef, Use of latent fingerprints as a source of DNA for genetic identification. Progress in Forensic Genetics 8, 2000.

33. Caragine, T., et al., Validation of Testing and Interpretation Protocols for Low Template DNA Samples Using AmpFISTR (R) Identifiler (R). Croatian Medical Journal, 2009. 50(3): p. 250-267.

34. Davis, C.P., et al., Multiplex Short Tandem Repeat Amplification of Low Template DNA Samples with the Addition of Proofreading Enzymes. Journal of Forensic Sciences, 2011. 56(3): p. 726732.

35. Hawthorne, M. "Systematic Methods of Identification." Fingerprints: Analysis and Understanding. 1st ed. Boca Raton, FL: CRC, 2009. 15-25. Print.

36. Babler, W.J., Embryologic development of epidermal ridges and their configurations. Birth Defects Original Article Series, 1991. 27(2): p. 18.

37. Holt, S., The Genetics of Dermal Ridges. 1968, Springfield, Ill: Charles C. Thomas. 195.

38. Justice, U.S.D.o. and F.B.o. Investigation, Processing Guide for Developing Latent Prints. 2001, Washington, D.C.: Federal Bureau of Investigation. 103.

39. Lennard, C., The Detection and Enhancement of Latent Fingerprints, in INTERPOL Forensic Science Symposium. 2001: Lyon, France. p. D2-89-90. 
40. Zamir, A., C. Oz, and B. Geller, Threat Mail and Forensic Science: DNA Profiling from Items of Evidence After Treatment with DFO. Journal of Forensic Sciences, 2000. 45(2): p. 2.

41. Van Hoofstat, D., et al., DNA typing of fingerprints using capillary electrophoresis: Effect of dactyloscopic powders. Electrophoresis, 1999. 20(14): p. 7.

42. Zamir, A., E. Springer, and B. Glattstein, Fingerprints and DNA: STR Typing of DNA Extracted from Adhesive Tape after Processing for Fingerprints. Journal of Forensic Science, 2000. 45(3): p. 2.

43. Andersen, J. and S. Bramble, The Effects of Fingermark Enhancement Light Sources on Subsequent PCR-STR DNA Analysis of Fresh Bloodstains. Journal of Forensic Sciences, 1997. 42(2): p. 4.

44. Roux, C., et al., A Further Study to Investigate the Effect of Fingerprint Enhancement Techniques on the DNA Analysis of Bloodstains. Journal of Forensic Identification, 1999. 49(4): p. 20.

45. Schulz, M.M. and W. Reichert, Archived or directly swabbed latent fingerprints as a DNA source for STR typing. Forensic Science International, 2002. 127(1-2): p. 128-130.

46. Pesaresi, M., et al., Qualitative and quantitative analysis of DNA recovered from fingerprints. International Congress Series, 2003. 1239: p. 5.

47. Alessandrini, F., et al., Fingerprints as Evidence for a Genetic Profile: Morphological Study on Fingerprints and Analysis of Exogenous and Individual Factors Affecting DNA Typing. Journal of Forensic Science, 2003. 48(3): p. 7.

48. Daly, D.J., C. Murphy, and S.D. McDermott, The transfer of touch DNA from hands to glass, farbic and wood. Forensic Science International: Genetics, 2011. In Press: p. 6.

49. Horsman-Hall, K.M., et al., Development of STR profiles from firearms and fired cartridge cases. Forensic Science International: Genetics, 2009. 3(4): p. 242-250.

50. Raymond, J., et al., The Effect of Common Fingerprint Detection Techniques on the DNA Typing of Fingerprints Deposited on Different Surfaces. Journal of Forensic Identification, 2004. 54(1): $p$. 23.

51. Kanable, R., DNA from Fingerprints? Law Enforcement Technology, 2005. 32(7): p. 1-4.

52. Schulz, M.M., et al., Ninhydrin-dyed latent fingerprints as a DNA source in a murder case. Journal of Clinical Forensic Medicine, 2004. 11(4): p. 3.

53. Raymond, J., C. Roux, and S.J. Walsh, Friction Ridge Skin: Interactions between Fingerprint Detection and DNA/Biological Material. Wiley Encyclopedia of Forensic Science, 2009: p. 5.

54. Anslinger, K., et al., Ninhydrin treatment as a screening method for the suitability of swabs taken from contact stains for DNA analysis. International Journal of Legal Medicine, 2004. 118(2): p. 122-124.

55. Grubwieser, P., et al., Systematic study on STR profiling on blood and saliva traces after visualization of fingerprint marks. Journal of Forensic Sciences, 2003. 48(4): p. 733-741.

56. Bhoelai, B., et al., Effect of common fingerprint detection techniques on subsequent STR profiling. Forensic Science International: Genetics Supplement Series, 2011. 3(1): p. e429-e430.

57. Balogh, M.K., et al., Fingerprints from Fingerprints. International Congress Series, 2003. 1239: p. 5.

58. Sewell, J., et al., Recovery of DNA and fingerprints from touched documents. Forensic Science International: Genetics, 2008. 2(4): p. 5.

59. Balogh, M.K., et al., STR genotyping and mtDNA sequencing of latent fingerprint on paper. Forensic Science International, 2003. 137(2-3): p. 8.

60. Lake County Crime Laboratory. Document BI 17.0. ABI310 Setup/RunProcedure. Lake County Crime Laboratory Biology Procedure Manual. Issue Date: 1 October 2001. Last Revision Date: 1 April 2009. Acquired 27 June 2012.

61. United States District Court for the Western District of Wisconsin. Life Technologies Corporation Licensed Usage. Digital image. Invitrogen.com, 29 Nov. 2011. Web. 1 July 2012. Available from: 
http://www.invitrogen.com/etc/medialib/files/Human-

Identification/PDFs.Par.94306.File.dat/Promega\%20Court\%20Notice\%20(158893 1)\%20(3).pdf. 